\title{
O programie badawczym teorii inteligentnego projektu *
}

Teoria inteligentnego projektu (ID - intelligent design), powstała i rozwijana obecnie głównie w Stanach Zjednoczonych, głosi, że w świecie przyrody, w różnych zjawiskach biologicznych i kosmicznych, dostrzegalny jest projekt, którego twórcą jest jakaś celowo działająca istota inteligentna (może być ona nadnaturalna, jak Bóg, ale i naturalna, stanowiąca byt fizyczny). Według zwolenników tej koncepcji wniosek o istnieniu takiego projektu nie wynika z założeń filozoficznych, metafizycznych, religijnych czy ideologicznych. Utrzymują oni, że jego podstawą są przesłanki o charakterze empirycznym (charakterystyczne cechy struktur przyrodniczych, które traktowane są jako skutki aktywności istot inteligentnych), a sama teoria ma status naukowy. Teoria inteligentnego projektu ma być naukową alternatywą dla koncepcji respektujących regułę naturalizmu metodologicznego, czyli takich, które na gruncie nauk przyrodniczych nie biorą pod uwagę możliwości udziału przyczyn inteligentnych w historii świata przyrody, lecz rozpatrują jedynie działanie czynników dających się ująć w kategoriach konieczności i przypadku. Najczęstszym celem ataków zwolenników tej teorii, zwanych teoretykami projektu, jest darwinizm (a raczej jego współczesna odmiana - neodarwinizm).

W wyżej wspomnianym rozumieniu naturalizmu metodologicznego przyczyny naturalne przeciwstawiane są przyczynom inteligentnym, a więc do koncepcji przyjmujących tę regułę nie zaliczałyby się teorie dotyczące inteligentnej

\footnotetext{
*Praca naukowa finansowana ze środków na naukę w latach 2008-2010 jako projekt badawczy.
} 
aktywności ludzkiej lub zwierzęcej czy nawet postulujące aktywność inteligentnych istot pozaziemskich. Bardzo często naturalizm metodologiczny rozumiany jest jednak słabiej, jako wykluczający z rozważań tylko pewien rodzaj przyczyn inteligentnych - przyczyny nadnaturalne - ale w sporze $\mathrm{z}$ teorią inteligentnego projektu, która nie postuluje nadnaturalnego projektanta, rozróżnienie na te dwa typy przyczyn - inteligentne nadnaturalne i inteligentne naturalne - ulega zatarciu i w istocie krytycy sprowadzają naturalizm metodologiczny do koncepcji wykluczającej z dociekań naukowych jakiekolwiek przyczyny inteligentne - oczywiście jedynie w ramach określonych obszarów takich nauk jak biologia czy kosmologia, mianowicie obszarów, w których bada się historię powstania i rozwoju Wszechświata, życia i jego form. ${ }^{1}$

Celem artykułu jest przedstawienie różnych badań, jakie można prowadzić w ramach teorii inteligentnego projektu, co stanowi odpowiedź na zarzut, że teoria ta nie stworzyła lub nawet nie jest w stanie stworzyć płodnego naukowego programu badawczego, czyli że jest ,hamulcem” nauki. ${ }^{2} \mathrm{~W}$ lepszym zrozumie-

\footnotetext{
${ }^{1} \mathrm{~W}$ sprawie rozumienia naturalizmu metodologicznego jako wykluczającego zarówno wyjaśnienia nadnaturalistyczne, jak i teleologiczne, w sensie powoływania się na przyczyny inteligentne, które nie są lub nie muszą być nadnaturalne, por.: Piotr BYLICA, „Naturalizm nauk przyrodniczych a konflikt między nauką a religią", Kwartalnik Filozoficzny 2007, t. 35, z. 2, s. 150, 153 [147-159]; Piotr ByLica, „Darwin o celowości w przyrodzie”, Kwartalnik Historii Nauki i Techniki 2008, nr 3-4, s. 259 [259-273], http://www.nauka-a-religia.uz.zgora.pl/index.php?action=tekst \&id=176 (17.02.2013); Piotr BylicA, „Główne założenia i problemy teizmu naturalistycznego w sprawie relacji sfery nadprzyrodzonej i świata przyrodniczego", w: Wiesław Dyк (red.), Biosfera. Człowiek i jego środowisko w aspekcie przyrodniczym, filozoficznym i teologicznym. Sozologia systemowa, t. IV, Wydawnictwo Naukowe Uniwersytetu Szczecińskiego, Szczecin 2012, s. 60 [55-95]; Piotr Bylica and Dariusz SAGan, „God, Design, and Naturalism: Implications of Methodological Naturalism in Science for Science-Religion Relation”, Pensamiento 2008, vol. 64, no. 242, s. 623 [621-638], http://www.nauka-a-religia.uz.zgora.pl/index.php?action=tekst\&id $=146(17.02 .2013)$.

${ }^{2}$ Por. Barbara Forrest and Paul R. Gross, Creationism's Trojan Horse: The Wedge of Intelligent Design, Oxford University Press, New York 2004, s. 39; Michael SHERmER, Why Darwin Matters: The Case Against Intelligent Design, Times Books, Henry Holt and Company, New York 2006, s. 99, 110-111; Kenneth R. Miller, Only a Theory: Evolution and the Battle for America's Soul, Viking, New York 2008, s. 86-87; John V. Aliff, „Teaching Evolution and the Challenge of Intelligent Design: A Symposium”, Georgia Journal of Science 2005, vol. 63, no. 3, s. 144 [144-152], http://facstaff.gpc.edu/ jaliff/GAJSci63-3.pdf (15.02.2010); Keith B. MilLer, „Countering Public Misconceptions About the Nature of Evolutionary Science”, Georgia Journal of Science 2005, vol. 63, no. 3, s. 179 [175-189], http://facstaff.gpc.edu/ jaliff/GAJSci63-3.pdf
} 
niu treści tej części artykułu, w której wspomniany cel zostanie zrealizowany, powinno pomóc uprzednie zapoznanie się z najważniejszymi pozytywnymi ideami formułowanymi w ramach teorii inteligentnego projektu. Od zaprezentowania tych idei zatem zaczniemy.

\section{Główne pozytywne koncepcje teorii inteligentnego projektu}

\section{Nieredukowalna złożoność}

W 1996 roku ukazało się pierwsze anglojęzyczne wydanie książki Michaela Behe'ego, zatytułowanej Czarna skrzynka Darwina. Biochemiczne wyzwanie dla ewolucjonizmu. ${ }^{3}$ Według Behe'ego istnieją układy biochemiczne, nazywane przez niego mechanizmami molekularnymi, posiadające pewną cechę, która stanowi ogromną przeszkodę dla wyjaśnienia ich w kategoriach ślepych procesów przyrodniczych, takich jak mechanizm neodarwinowski. Cechą tą jest nieredukowalna złożoność (irreducible complexity). ${ }^{4}$ Oznacza to, że układ charakteryzujący się nieredukowalną złożonością od samego początku swojego istnienia musi składać się z co najmniej kilku współdziałających części, aby mógł spełniać swoją funkcję, a usunięcie choćby jednej z nich prowadzi do utraty funkcjonalności układu. Zdaniem Behe’ego żaden taki układ nie mógł zatem wyewoluować w stopniowym procesie neodarwinowskim, gdyż nie mogły ist-

(15.02.2010); Robert T. Pennock, Tower of Babel: The Evidence Against the New Creationism, MIT Press - A Bradford Book, Cambridge, Massachusetts 1999, s. 292, 294; Richard Dawkins, Bóg urojony, przel. Piotr Szwajcer, Wydawnictwo CiS, Warszawa 2007, s. 184; Massimo Pigliucc, Denying Evolution: Creationism, Scientism and the Nature of Science, Sinauer Associates, Sunderland, Massachusetts 2002, s. 66-67.

${ }^{3}$ Michael J. Beнt, Czarna skrzynka Darwina. Biochemiczne wyzwanie dla ewolucjonizmu, przeł. Dariusz Sagan, Biblioteka Filozoficznych Aspektów Genezy, t. 4, Wydawnictwo MEGAS, Warszawa 2008. Polski przekład obejmuje również posłowie, które Behe dołączył do edycji książki z 2006 roku, opublikowanej z okazji dziesięciolecia ukazania się pierwszego wydania.

${ }^{4}$ Behe twierdzi, że termin ten wymyślił niezależnie, ale w 1986 roku — o czym Behe dowiedział się później — został on użyty w podobnym znaczeniu przez biologa teoretycznego Michaela J. Katza z Case Western Reserve University w książce Templates and Explanation of Complex Patterns, Cambridge University Press, Cambridge 1986 (por. BeHE, Czarna skrzynka Darwina..., s. 221 przyp. 158; Jonathan Wells, The Politically Incorrect Guide to Darwinism and Intelligent Design, Regnery Publishing, Inc., Washington, DC. 2006, s. 108). 
nieć żadne pełniące tę samą funkcję układy poprzedzające, $\mathrm{z}$ których miałby się on rozwinąć. Behe dopuszcza możliwość, że nieredukowalna złożoność mogła powstać jakąś okrężną drogą ewolucyjną. Jednak jego zdaniem, im system jest bardziej złożony, tym mniejsze prawdopodobieństwo, że powstał on w ten sposób. ${ }^{5} \mathrm{~W}$ jego przekonaniu najlepszym wyjaśnieniem powstania tego typu układów jest pogląd, że zostały one zaprojektowane przez jakiś inteligentny czynnik.

Ulubionym przykładem systemu nieredukowalnie złożonego, jakim Behe posługuje się w celu zilustrowania swojej tezy, jest standardowa, pięcioczęściowa pułapka na myszy, jakiej używamy w domu. Wszystkie części pułapki podstawa, sprężyna, młoteczek, drążek przytrzymujący i zapadka — są niezbędne do jej funkcjonowania jako urządzenia do łapania myszy. Gdyby zabrakło choćby jednego składnika, pułapka na myszy nie mogłaby działać. Według Behe'ego podobne - choć znacznie bardziej skomplikowane — układy znajdują się w komórce. Są to między innymi: wić bakteryjna, rzęska eukariotyczna, kaskada krzepnięcia krwi, transport wewnątrzkomórkowy i system immunologiczny. Omówmy jeden przykład.

Niektóre bakterie poruszają się za pomocą wici. Można powiedzieć, że wić jest biochemicznym odpowiednikiem silnika zaburtowego, wykorzystywanego w motorówkach, w tym sensie, że jest to mechanizm obrotowy. Jest to dhugie włoskowate włókno zwane filamentem, wystające z błony komórkowej. Filament jest utworzony z białka zwanego flagelliną. Styka się on z płynem otaczającym bakterię i poruszając się, przemieszcza ją w wybranym kierunku. Filament jest przymocowany za pomocą molekuły zwanej „białkiem haka” do wału obrotowego, mieszczącego się tuż przy powierzchni komórki. Wał obrotowy (rotor) przytwierdzony jest do silnika, który znajduje się u podstawy wici, co oznacza, że odizolowany filament jest bezużyteczny. Stator utrzymuje natomiast wszystkie te elementy w stanie stacjonarnym w płaszczyźnie błony komórkowej. Wić potrzebuje do funkcjonowania przynajmniej tych trzech składników filamentu, wału obrotowego i silnika - jest więc, zdaniem Behe'ego, nieredukowalnie złożona. ${ }^{6}$

\footnotetext{
${ }^{5}$ Por. Behe, Czarna skrzynka Darwina..., s. 43.

${ }^{6}$ Por. Behe, Czarna skrzynka Darwina..., s. 67-69.
} 
Wić bakteryjna to przykład konkretnego rodzaju systemu umożliwiającego pływanie. Aby mógł spełniać swoje zadanie, każdy taki układ — biochemiczny czy jakikolwiek inny - musi składać się z co najmniej trzech części: elementu popychającego, silnika z zapewnionym źródłem zasilania oraz łącznika, który przenosi energię z silnika do elementu popychającego (w przypadku wici są to filament, silnik i wał obrotowy). Koniecznym warunkiem funkcjonowania tego typu układów jest równoczesna obecność wszystkich tych składników. W rzeczywistości układy pływające mogą być bardziej złożone i do sprawnego działania wymagać więcej części. Wić bakteryjną konstytuuje około 50 rodzajów białek, z których co najmniej 20 składa się na ukończoną strukturę wici, zaś reszta jest potrzebna do jej zbudowania, funkcjonowania i utrzymania. ${ }^{7} \mathrm{~W}$ celu określenia roli i znaczenia wielu $\mathrm{z}$ tych białek trzeba przeprowadzić dalsze badania. Behe sugeruje jednak, że im większa liczba części niezbędnych do funkcjonowania, tym mniejsze prawdopodobieństwo powstania układów nieredukowalnie złożonych drogą darwinowskiej ewolucji.

Należy także pamiętać — mówi Behe - że składniki układów służących do pływania muszą być do siebie odpowiednio dopasowane. Element popychający nie może mieć zbyt dużej powierzchni w stosunku do silnika i łącznika, bo te mogłyby nie wytrzymać naprężenia w trakcie pracy i ulec zniszczeniu. Element popychający musi mieć jednak na tyle dużą powierzchnię, by można było dzięki niemu pokonać pożądaną odległość we właściwym czasie. Oprócz tego coś musi kontrolować tempo i kierunek ruchu: „W bezwzględnym świecie przyrody organizm tracący energię na bezradne wymachiwanie w wodzie nie miałby żadnej przewagi nad organizmem dryfującym łagodnie obok". ${ }^{8}$

${ }^{7}$ Por. Lucy Shaprio, „The Bacterial Flagellum: From Genetic Network to Complex Architecture”, Cell 1995, vol. 80, s. 525 [525-527] (cyt. za: Michael J. BeHE, „Intelligent Design Theory as a Tool for Analyzing Biochemical Structures”, w: William A. Dembski (ed.), Mere Creation: Science, Faith \& Intelligent Design, InterVarsity Press, Downers Grove, Illinois 1998, s. 180 [177194]).

${ }^{8}$ BeHE, Czarna skrzynka Darwina..., s. 57. Omówienie koncepcji nieredukowalnej złożoności w języku polskim można znaleźć też w: Dariusz SAGAN, Spór o nieredukowalną zlożoność układów biochemicznych, Biblioteka Filozoficznych Aspektów Genezy, t. 5, Wydawnictwo MEGAS, Warszawa 2008, http://www.nauka-a-religia.uz.zgora.pl/index.php?action=tekst\&id=150 (17.02.2013); Dariusz SAGAN, „Trzy płaszczyzny argumentu z nieredukowalnej złożoności”, $\mathrm{Na}$ Poczatku ... 2005, R. 12, nr 5-6 (194-195), s. 162-224, http://www.nauka-a-religia.uz.zgora.pl/in dex.php?action=tekst\&id=75 (10.08.2009); Dariusz SAGAN, „Michaela Behe'ego koncepcja niere- 


\section{Wyspecyfikowana zlożoność i informacja}

Intelektualnym wkładem innego teoretyka projektu, Stephena C. Meyera, w rozwój pozytywnej argumentacji teorii inteligentnego projektu jest wskazywanie, jakie cechy organizmów żywych mogą świadczyć o projekcie. Kontynuując dociekania autorów The Mystery of Life's Origin [Zagadka pochodzenia życia] i pozostałych autorów podręcznika Of Pandas and People [O pandach i ludziach] (był on współautorem noty dla nauczycieli w drugim jego wydaniu), czyli pionierskich książek w historii współczesnej teorii inteligentnego projektu, Meyer wykorzystuje bazujące na teorii informacji pojęcie wyspecyfikowanej złożoności (specified complexity), ${ }^{9}$ odnosząc je do bogatych w informację struktur biologicznych. Samo pojęcie pochodzi od badacza pochodzenia życia Lesliego Orgela, według którego „charakterystyczną cechą organizmów żywych jest wyspecyfikowana złożoność. Kryształy, takie jak granit, nie są ożywione, ponieważ brak im złożoności. Mieszanki losowych polimerów nie są ożywione, gdyż brak im specyficzności". ${ }^{10}$ Aby można było powiedzieć, że dana struktura jest złożona, a więc bogata w informację, musi być ona aperiodyczna, czyli charakteryzować się małym stopniem uporządkowania. Na przykład książka zawierająca tylko jedno, powtarzające się w kółko zdanie byłaby wysoce uporządkowana, ale niosłaby niewiele informacji. Jednak nie każda aperiodyczna struktura

dukowalnej złożoności”, Na Początku... 2003, R. 11, nr 11-12A (174-175), s. 402-417, http:// www.nauka-a-religia.uz.zgora.pl/index.php?action=tekst\&id=22 (10.08.2009); Dariusz SAGAN, „Ewaluacja ewolucjonistycznych rozwiązań problemu nieredukowalnej złożoności”, Otwarte Referarium Filozoficzne 2009, t. 2, s. 89-116, http://www.nauka-a-religia.uz.zgora.pl/index.php?acti on=tekst\&id=160 (17.02.2013); Dariusz SAGAN, „Teleologiczne wyjaśnienie nieredukowalnej złożoności układów biochemicznych", Roczniki Filozoficzne 2006, t. LIV, nr 1, s. 139-160; Piotr ByLICA, „Testowalność teorii inteligentnego projektu”, Filozofia Nauki 2003, nr 2 (42), s. 46-47 [4149], http://www.nauka-a-religia.uz.zgora.pl/index.php?action=tekst\&id=31 (17.02.2013); Piotr ByLICA, „Ruch Inteligentnego Projektu”, Przeglad Filozoficzny - Nowa Seria 2004, nr 2 (50), s. 103-104 [100-109].

${ }^{9}$ Por. Charles B. Thaxton, Walter L. Bradley, and Roger L. Olsen, The Mystery of Life's Origin: Reassessing Current Theories, 2nd ed., Lewis and Stanley, Dallas, Texas 1992, s. 129130, http://www.themysteryoflifesorigin.org/ (17.02.2009); Dean H. KenYon and Percival Davis, Of Pandas and People: The Central Question of Biological Origins, 2nd ed., Haughton Publishing Company, Dallas, Texas 1993, s. 55-57.

${ }^{10}$ Leslie Orget, The Origins of Life, John Wiley, New York 1973, s. 189 (cyt. za: Thaxton, Bradley, and Olsen, The Mystery of Life's Origin..., s. 130, 142). 
może być charakterystyczna dla życia, ponieważ nie każda niesie sensowną informację — w przypadku organizmów żywych utożsamianą z użyteczną funkcją biologiczną. ${ }^{11}$

Pojęcie wyspecyfikowanej złożoności Meyer stosuje do szerokiego spektrum zagadnień dotyczących pochodzenia dużej ilości informacji potrzebnej do utworzenia nowych genów, białek, typów komórek czy planów budowy ciała. Wskazuje on, że żaden scenariusz naturalistyczny nie thumaczy tego zjawiska, natomiast niezmiernie łatwo wyjaśnia je teoria inteligentnego projektu. Wiemy, że istoty inteligentne - ludzie - tworzą wyspecyfikowaną złożoność, a zatem inteligencja stanowi adekwatną przyczynę wyspecyfikowanej złożoności. Meyer argumentuje dalej, że skoro jedyną znaną nam adekwatną przyczyną wyspecyfikowanej złożoności jest inteligencja, to stosując wnioskowanie do najlepszego wyjaśnienia, należy uznać, iż biologiczna wyspecyfikowana złożoność także jest wytworem inteligencji. ${ }^{12}$

W 2009 roku ukazała się pierwsza książka Meyera - Signature in the Cell: DNA and the Evidence for Intelligent Design [Podpis w komórce: DNA i świadectwa na rzecz inteligentnego projektu]. ${ }^{13}$ Meyer gromadzi w niej swoje wieloletnie przemyślenia, wyrażane wcześniej w różnych mniejszych publikacjach, na temat świadectw na rzecz inteligentnego projektu, jakie można dostrzec w będącym nośnikiem informacji cyfrowym kodzie DNA oraz w różnych dużych cząsteczkach biologicznych. ${ }^{14}$ Wzorując się na O powstawaniu gatunków Darwina, ${ }^{15}$ prezentuje on „długi szereg dowodzeń”, tyle że niepro-

\footnotetext{
${ }^{11}$ Por. Thaxton, Bradley, and Olsen, The Mystery of Life's Origin..., s. 129-130.

${ }^{12}$ Por. Stephen C. MeYer, „The Origin of Biological Information and the Higher Taxonomic Categories", Proceedings of the Biological Society of Washington 2004, vol. 117 (2), s. 216-217, 230-234 [213-239], http://www.discovery.org/scripts/viewDB/index.php?command=view\&id=21 77 (31.03.2009), przedruk w: William A. Dembski (ed.), Darwin's Nemesis: Phillip Johnson and the Intelligent Design Movement, InterVarsity Press, Downers Grove, Illinois 2006, s. 174-213; Thaxton, Bradley, and Olsen, The Mystery of Life's Origin..., s. 211.

${ }^{13}$ Stephen C. Meyer, Signature in the Cell: DNA and the Evidence for Intelligent Design, HarperOne, New York 2009.

${ }^{14}$ Por. Meyer, Signature in the Cell..., s. 5, 7.

${ }^{15}$ Por. Karol DARwin, $O$ powstawaniu gatunków drogą doboru naturalnego, czyli o utrzymaniu się doskonalszych ras w walce o byt, przeł. Szymon Dickstein i Józef Nusbaum, Edicio-
} 
wadzący do wniosku o mocy i wystarczalności procesów naturalnych, lecz wskazujący, że powstanie życia wymagało działania przyczyny inteligentnej. ${ }^{16}$ Signature in the Cell to również kompendium metodologicznych podstaw teorii inteligentnego projektu i ogólnie nauk o pochodzeniu.

\section{Filtr eksplanacyjny}

Kolejny argument został opracowany przez matematyka i filozofa Williama Dembskiego. W 1998 roku opublikował on książkę The Design Inference: Eliminating Chance Through Small Probabilities [Wnioskowanie o projekcie: eliminacja przypadku na podstawie małych prawdopodobieństw], ${ }^{17} \mathrm{~W}$ której zaprezentował pierwszą szczegółowo opracowaną statystyczną metodę empirycznego wykrywania projektu, którą nazywa filtrem eksplanacyjnym.

Filtr eksplanacyjny jest czymś w rodzaju trójstopniowego sita. Chcąc zbadać, czy dane zjawisko jest wynikiem projektu, musimy je poddać analizie w trzech trybach wyjaśniania: konieczności, przypadku i projektu. Najpierw należy określić, czy badane zdarzenie jest przygodne czy konieczne. Jeśli da się je wyjaśnić jakimś prawem przyrody, to można uznać, że owo zdarzenie jest wynikiem konieczności - nie mogło zajść w inny sposób. Jeżeli jednak nie można go wyjaśnić żadnym prawem, to sprawdzanie trwa dalej. Na drugim etapie filtra szacuje się stopień złożoności tego zdarzenia, będący odwrotnością miary prawdopodobieństwa. Jeżeli zdarzenie charakteryzuje się niewielką złożonością, to można przypisać je przypadkowi. Jednak wraz ze zwiększaniem się złożoności prawdopodobieństwo jego zaistnienia staje się coraz mniejsze i coraz bardziej można wątpić w jego przypadkowość. W ten sposób dochodzimy do trzeciego stopnia filtra eksplanacyjnego. Sama złożoność (czyli małe prawdopodobieństwo) nie wystarczy do wyciągnięcia wniosku o projekcie. Jeśli podrzucimy rzetelną monetę tysiąc razy, to wynik tego zdarzenia będzie bardzo mało prawdo-

nes Altaya Polska \& DeAgostini Polska, Warszawa 2001, s. 529.

${ }^{16}$ Por. Meyer, Signature in the Cell..., s. 8.

${ }^{17}$ William A. Dembski, The Design Inference: Eliminating Chance Through Small Probabilities, Cambridge Studies in Probability, Induction, and Decision Theory, Cambridge University Press, Cambridge 1998. 
podobny, ale jednak przypadkowy. Aby można było wnioskować o projekcie, zdarzenie musi ponadto pasować do jakiegoś obiektywnego, niezależnego wzorca - specyfikacji (specification). Wzorcem tego typu może być na przykład długi (czyli złożony) ciąg liczb pierwszych, jaki wykryli badacze SETI w filmie Kontakt, który nakręcono na podstawie powieści Carla Sagana pod tym samym tytułem. Według Dembskiego badacze ci uznali, że odebrany przez nich sygnał (był to ciąg liczb pierwszych od 2 do 101) pochodzi od jakiejś inteligencji, ponieważ jest złożony i wyspecyfikowany. Ostatecznym kryterium wykrywania projektu jest więc wyspecyfikowana złożoność. ${ }^{18}$ (Dembski posługuje się tym samym pojęciem, co Meyer i pionierzy teorii inteligentnego projektu, ale to on nadał mu ścisłe znaczenie techniczne.)

Według Dembskiego filtr eksplanacyjny stanowi formalizację i uściślenie procesu wnioskowania, stosowanego niemal nieustannie w życiu codziennym, a nawet w niektórych naukach, takich jak archeologia czy kryptografia, kiedy podejmowane są próby rozstrzygnięcia, czy dane zdarzenie jest wynikiem zaprojektowania przez istotę inteligentną. Zaletą filtra - o ile koncepcja ta jest słuszna - jest to, że ma on charakter interdyscyplinarny, gdyż jako procedura wnioskowania o projekcie może mieć zastosowanie w wielu odrębnych dziedzinach wiedzy. ${ }^{19}$

\footnotetext{
${ }^{18}$ Por. William A. Dembski, „Powrót projektu do nauk przyrodniczych”, przeł. Dariusz Sagan, w: Kazimierz JodKowsKi (red.), Teoria inteligentnego projektu - nowe rozumienie naukowości?, Biblioteka Filozoficznych Aspektów Genezy, t. 2, Wydawnictwo MEGAS, Warszawa 2007, s. 16-19 [11-24], http://www.nauka-a-religia.uz.zgora.pl/index.php?action=tekst\&id=138 (17.02.2013).

${ }^{19}$ Por. Thomas Woodward, Doubts about Darwin: A History of Intelligent Design, Baker Books, Grand Rapids, Michigan 2003, s. 173. Omówienie koncepcji filtra eksplanacyjnego w języku polskim można znaleźć też w: Dariusz SAGAN, „Filtr eksplanacyjny: wykrywanie inteligentnego projektu na gruncie nauk przyrodniczych", Roczniki Filozoficzne 2009, t. LVII, nr 1, 157 193, http://www.nauka-a-religia.uz.zgora.pl/index.php?action=tekst\&id=186 (17.02.2013); BYLICA, „Testowalność...”, s. 43-46; ByLICA, „Ruch Inteligentnego Projektu...”, s. 104-105; Kazimierz JoDKowski, „Rozpoznawanie genezy: istota sporu ewolucjonizm-kreacjonizm”, Roczniki Filozoficzne 2002, t. L, z. 3, s. 194-197 [187-198], http://www.nauka-a-religia.uz.zgora.pl/index.php?ac tion=tekst\&id=32 (17.02.2013).
} 


\section{Sformulowanie teorii inteligentnego projektu w kategoriach teorii informacji}

Dembski intensywnie pracuje również nad sformułowaniem teorii inteligentnego projektu w kategoriach teorii informacji, sprawdzając przy tym twierdzenia biologii ewolucyjnej $\mathrm{w}$ zakresie tworzenia informacji biologicznej. Pierwsze rozważania na ten temat przedstawił w artykule z 1997 roku, ${ }^{20}$ a następnie rozwinąl je (i nadal rozwija) w innych publikacjach, między innymi w książkach: Intelligent Design: The Bridge Between Science \& Theology [Teoria inteligentnego projektu: most między nauką a teologią] ${ }^{21}$ i No Free Lunch: Why Specified Complexity Cannot Be Purchased without Intelligence [Nic za darmo: dlaczego wyspecyfikowanej złożoności nie da się wyjaśnić bez odwołania do inteligencji]. ${ }^{22} \mathrm{~W}$ ramach tej działalności Dembski wraz $\mathrm{z}$ innymi uczonymi założył stronę internetową The Evolutionary Informatics Lab (http://evoinfo.org).

Dembski argumentuje, że informacja jest „niezawodnym wskaźnikiem projektu i właściwym przedmiotem badań naukowych". ${ }^{23}$ Informację traktuje on jako miarę złożoności - im większa złożoność, tym większa ilość informacji. Aby dane zdarzenie było złożone, musi być ono przygodne. Ponieważ deterministyczne prawa dopuszczają tylko jeden sposób zajścia danego zdarzenia, z zasady nie mogą tworzyć ani prostej, ani złożonej informacji, a mogą co najwyżej kierować przepływem informacji już istniejącej albo zmniejszać jej ilość (gdy na przykład dane ulegają kompresji). Złożoną informację mogą tworzyć natomiast

\footnotetext{
${ }^{20}$ Por. William A. Dembski, „Intelligent Design as a Theory of Information”, w: Robert T. PeNNock (ed.), Intelligent Design Creationism and Its Critics: Philosophical, Theological, and Scientific Perspectives, MIT Press - A Bradford Book, Cambridge, Massachusetts 2001, s. 553573, przedruk z: Perspectives on Science and Christian Faith 1997, vol. 49, no. 3, s. 180-190, http://www.asa3.org/ASA/PSCF/1997/PSCF9-97Dembski.html (02.04.2009).

${ }^{21}$ Por. William A. Dembski, Intelligent Design: The Bridge Between Science \& Theology, InterVarsity Press, Downers Grove, Illinois 1999, s. 153-183.

${ }^{22}$ Por. William A. Dembski, No Free Lunch: Why Specified Complexity Cannot Be Purchased without Intelligence, Rowman \& Littlefield Publishers, Inc., Lanham, Maryland 2002, s. $125-237$.

${ }^{23}$ DemBSKI, Intelligent Design..., s. 18.
} 
procesy przypadkowe. Dlatego wskaźnikiem projektu nie może być jedynie złożona informacja, lecz taka, która charakteryzuje się ponadto specyfikacją. W celu odróżnienia informacji niepozwalającej na wnioskowanie o projekcie od informacji, która się do tego nadaje, Dembski ukuł więc termin złożona wyspecyfikowana informacja (complex specified information — w skrócie „CSI"). Dembski utrzymuje zatem, że przypadek może generować informację złożoną i niewyspecyfikowaną, jak również informację niezłożoną i wyspecyfikowaną, ale nie potrafi tworzyć złożonej i wyspecyfikowanej informacji — jest to zbyt mało prawdopodobne. Co więcej, utrzymuje on, że źródłem złożonej wyspecyfikowanej informacji nie mogą być również procesy stochastyczne, czyli połączone działanie konieczności i przypadku - skoro konieczność i przypadek nie są w stanie dokonać tego z osobna, to i razem nie mogą się do tego nadawać. Prawa deterministyczne tylko transmitują dostarczoną im CSI, a skoro przypadek nie tworzy CSI, to nie może jej dostarczyć prawom. Dembski odrzuca zatem możliwość, że CSI mogą generować algorytmy genetyczne lub darwinowski mechanizm mutacji i doboru naturalnego. Jedyną znaną przyczyną powstawania złożonej wyspecyfikowanej informacji jest — jego zdaniem — inteligencja. ${ }^{24}$

W ujęciu Dembskiego złożona wyspecyfikowana informacja jest równoważna wyspecyfikowanej złożoności, która stanowi kryterium projektu w filtrze eksplanacyjnym. Istnieje między nimi jednak pewna różnica. Mimo iż jest z nim związana, ilość informacji nie jest mierzona prawdopodobieństwem, tak jak stopień złożoności zdarzenia w filtrze. Podobnie jak w teorii komunikacji, informację dogodniej mierzyć w bitach, a w tym celu prawdopodobieństwo przekształcane jest matematycznie za pomocą ujemnego logarytmu o podstawie 2. Miara informacji zawartej $\mathrm{w}$ zdarzeniu o prawdopodobieństwie $p$ zdefiniowana jest więc jako $-\log _{2} p{ }^{25}$

Tezę, że konieczność i przypadek, czyli przyczyny naturalne, ani osobno, ani razem nie potrafią tworzyć złożonej wyspecyfikowanej informacji, nazywa Dembski prawem zachowania informacji (law of conservation of information). Termin ten zapożyczony został od Petera Medawara, brytyjskiego biologa i lau-

\footnotetext{
${ }^{24}$ Por. Dembski, Intelligent Design..., s. 153-170; Dembsкi, No Free Lunch..., s. 140-141, 148-159.

${ }^{25}$ Por. Dembski, Intelligent Design..., s. 155-156; Dembsкi, No Free Lunch..., s. 126-127.
} 
reata Nagrody Nobla, który rozumiał przezeń prawo wykluczające tylko, że procesy deterministyczne mogą tworzyć nową złożoną informację, podczas gdy Dembski rozszerza je na procesy przypadkowe i stochastyczne. Jedną z bezpośrednich konsekwencji prawa zachowania informacji jest twierdzenie, że w zamkniętym układzie przyczyn naturalnych ilość złożonej wyspecyfikowanej informacji pozostaje stała lub maleje. Innym następstwem jest wykluczenie możliwości redukcjonistycznego wyjaśnienia złożonej wyspecyfikowanej informacji — przyczyna zaistnienia danej CSI musi zawierać tyle samo lub więcej CSI. ${ }^{26}$

\section{Korelacja zamieszkiwalności z mierzalnością}

W 2004 roku ukazała się książka The Privileged Planet: How Our Place in the Cosmos Is Designed for Discovery [Uprzywilejowana planeta: nasze miejsce w kosmosie zostało zaprojektowane dla dokonywania odkryćc], ${ }^{27} \mathrm{w}$ której przedstawiono nowy pozytywny argument na rzecz projektu. Autorzy książki to astronom Guillermo Gonzalez oraz filozof Jay W. Richards. Gonzalez jest dość znanym naukowcem - opublikował około siedemdziesiąt artykułów w renomowanych czasopismach naukowych, takich jak The Astrophysical Journal, The Astronomical Journal, Astronomy and Astrophysics, Icarus czy Monthly Notices of the Royal Astronomical Society. Współpracował między innymi z NASA, jak również z paleontologiem Peterem Wardem i astronomem Donaldem Brownlee, autorami cenionej książki Rare Earth: Why Complex Life Is Uncommon in the Universe [Nietypowa Ziemia: dlaczego złożone życie nie jest powszechne we Wszechświecie], ${ }^{28}$ której treść stanowi częściowe potwierdzenie tezy autorów The Privileged Planet. ${ }^{29}$ Razem z nimi Gonzalez opubli-

\footnotetext{
${ }^{26}$ Por. Dembsкi, Intelligent Design..., s. 170-174; Dembsкi, No Free Lunch..., s. 159-166.

${ }^{27}$ Guillermo Gonzalez and Jay W. Richards, The Privileged Planet: How Our Place in the Cosmos Is Designed for Discovery, Regnery Publishing, Inc., Washington 2004.
}

${ }^{28}$ Peter D. WARD and Donald Brownlee, Rare Earth: Why Complex Life Is Uncommon in the Universe, Copernicus Books, New York 2000. Argumentacja na rzecz podobnej tezy — że Ziemia może być jedyną planetą w naszej galaktyce, a może nawet w całym kosmosie, zamieszkałą przez inteligentne istoty — znajduje się również w książce: John GribBIn, Dlaczego jesteśmy. Cud powstania życia na Ziemi, przeł. Adam Tuz, Wiedza i Życie. Orbity Nauki, Prószyński i S-ka, Warszawa 2013.

${ }^{29}$ Por. Gonzalez and Richards, The Privileged Planet..., s. xii, 348 przyp. 12. 
kował artykuł, który trafił na okładkę październikowego numeru Scientific American z 2001 roku (w polskojęzycznym wydaniu tego czasopisma - Świecie Nauki - artykuł ten ukazał się w numerze grudniowym z tego samego roku). ${ }^{30}$ Tezę, którą szczegółowo dowodził wspólnie z Richardsem w The Privileged Planet, Gonzalez przedstawił po raz pierwszy na konferencji w Yale University w 2000 roku. ${ }^{31}$

Gonzalez i Richards starają się wykazać, że coraz to nowe świadectwa empiryczne przeczą zabarwionej naturalistycznie czy materialistycznie tezie tak zwanej zasady kopernikańskiej (inaczej nazywanej zasadą pośledniości lub zasadą obojętności), według której nasze miejsce w kosmosie nie jest ani wyjątkowe, ani celowo zamierzone; Ziemia — jak wyraził się Carl Sagan — jest tylko właściwie niczym niewyróżnioną „małą błękitną kropką” ${ }^{32}$ w bezmiarze Wszechświata, w którym życie jest zjawiskiem wysoce prawdopodobnym, a zatem musi istnieć wiele planet zamieszkiwanych przez organizmy żywe, w tym spory ułamek planet goszczących istoty inteligentne o dużym stopniu zaawansowania cywilizacyjnego i technologicznego. Gonzalez i Richards argumentują, że zaistnienie życia, a tym bardziej istot inteligentnych, wymaga jednoczesnego nałożenia się licznych szczególnych warunków, a więc prawdopodobieństwo jego powstania drastycznie maleje i Wszechświat najwyraźniej nie jest tak tętniący życiem (inteligentnym lub nie), jak przewiduje zasada kopernikańska. Co więcej - i tu leży istota ich argumentu - te same unikatowe warunki, które są konieczne do istnienia inteligentnego życia, zapewniają zarazem dogodną możliwość naukowego badania Wszechświata. Innymi słowy, „zamieszkiwalność” (habitability) koreluje z „mierzalnością” (measurability): ${ }^{33}$ „Fakt, że nasza atmosfera jest przejrzysta; że nasz księżyc ma właściwy rozmiar i znajduje się w odpowiedniej odległości od Ziemi i że jego grawitacja stabilizuje obrót Ziemi; że nasze umiejscowienie w naszej galaktyce jest właśnie takie; że nasze słońce

\footnotetext{
${ }^{30}$ Guillermo Gonzalez, Donald Brownlee i Peter D. Ward, ,Życie w nieprzyjaznym Wszechświecie”, przeł. Zbigniew Loska, Świat Nauki 2001, nr 12, s. 44-51.

${ }^{31}$ Por. Thomas Woodward, Darwin Strikes Back: Defending the Science of Intelligent Design, Baker Books, Grand Rapids, Michigan 2006, s. 48.

${ }^{32}$ Por. Carl SAGAN, Błękitna kropka. Człowiek i jego przyszlość w kosmosie, przeł. Marek Krośniak, Na Ścieżkach Nauki, Prószyński i S-ka, Warszawa 1996.

${ }^{33}$ Por. Gonzalez and Richards, The Privileged Planet..., s. x-xi.
} 
ma dokładnie taką a nie inną masę i skład - wszystkie te i wiele innych faktów to nie tylko konieczne warunki zamieszkiwalności Ziemi, ale i zdumiewające, kluczowe elementy dokonywania odkryć i pomiaru Wszechświata przez naukowców. Ludzkość ma niezwykle dogodną możliwość rozszyfrowywania kosmosu. Czy to po prostu szczęśliwy traf? Zbadanie Wszechświata przy pomocy najlepszych narzędzi współczesnej nauki prowadzi do wniosku, że miejsce charakteryzujące się odpowiednimi warunkami dla inteligentnego życia zapewnia też jego mieszkańcom wyjątkowo przejrzysty widok na Wszechświat. Te tak zwane strefy zamieszkiwalności są we Wszechświecie zjawiskiem nieczęstym, a nawet one mogą być pozbawione życia. Ale jeżeli istnieje gdzieś inna cywilizacja, ona również cieszy się dogodnym punktem obserwacyjnym, umożliwiającym przeszukiwanie kosmosu i być może znalezienie nas". ${ }^{34}$

Gonzalez i Richards nie są pierwszymi, którzy dostrzegli korelację między zamieszkiwalnością a mierzalnością. Wskazywali na nią przede wszystkim bio$\log$ molekularny Michael Denton ${ }^{35}$ oraz niemiecki filozof i historyk Hans Blumenberg, ale sugerowali ją także fizyk John Barrow, historyk nauki Stanley Jaki oraz astronomowie Michael Mendillo i Richard Hart. Nie podjęli się oni jednak rozwinięcia argumentu możliwego do sformułowania na podstawie tej korelacji. ${ }^{36}$

Jednego z licznych przykładów korelacji między zamieszkiwalnością a mierzalnością dostarcza układ Ziemia-Księżyc-Słońce. Masa ziemskiego księżyca stanowi znaczny ułamek masy Ziemi, dzięki czemu stabilizuje on nachylenie osiowe naszej planety, nie dopuszczając do dużej zmienności kąta nachylenia, a zbyt duży lub zbyt mały kąt miałby niekorzystne konsekwencje dla istot żywych. Za sprawą Księżyca nachylenie osiowe Ziemi waha się w wąskich granicach 22,1-24,5 stopnia na przestrzeni tysięcy lat, a obecnie wynosi 23,5 stopnia. Umożliwia to na przykład zmianę wzorca wiania wiatrów w skali roku, dzięki czemu sezonowe deszcze mogą zawitać do obszarów, które bez tego byłyby zawsze suche i zupełnie jałowe.

\footnotetext{
${ }^{34}$ Gonzalez and Richards, The Privileged Planet..., s. x-xi.

${ }^{35}$ Por. Michael Denton, Nature's Destiny: How the Laws of Biology Reveal Purpose in the Universe, The Free Press, New York 1998, s. 262, 372.

${ }^{36}$ Por. Gonzalez and Richards, The Privileged Planet..., s. 309-311.
} 
Samo powstanie Księżyca, który zgodnie z najpopularniejszym scenariuszem utworzył się po kolizji Ziemi z ciałem niebieskim o porównywalnej masie do Marsa, mogło mieć pośredni wpływ na życie. W wyniku kolizji Ziemia prawdopodobnie uległa stopieniu, przez co większa ilość ciekłego żelaza przedostała się do środka planety, formując ziemskie jądro, co pomogło z kolei utworzyć silne pole magnetyczne, które chroni życie przed niszczycielskim cząsteczkowym promieniowaniem słonecznym. Gdyby nie wspomniana kolizja, pierwotna gruba skorupa ziemska mogłaby uniemożliwić ruch płyt tektonicznych, a żelazo zalegające w skorupie ziemskiej znacznie opóźnić utlenienie atmosfery — oba te czynniki mają kluczowe znaczenie dla zamieszkiwalności naszej planety.

Słońce, Księżyc i Ziemia mają odpowiednie właściwości, takie jak skład (w przypadku Słońca), masa, rozmiar czy oddalenie względem siebie, bez których istnienie złożonych, inteligentnych istot żywych byłoby niemożliwe. Gonzalez i Richards wskazują na zaskakujący zbieg okoliczności, że te same właściwości układu Ziemia-Księżyc-Słońce, sprawiające, iż nasza planeta jest przyjazna inteligentnemu życiu, umożliwiają jednocześnie obserwację całkowitych zaćmień słonecznych z powierzchni Ziemi, co ma istotne znaczenie dla dokonywania odkryć naukowych. ${ }^{37}$

Zaćmienia obserwowane współcześnie mają szczególny charakter. Nie są to zaćmienia całkowite tego typu, jakie miały miejsce mniej więcej 2,5 miliarda lat temu, gdy - jak uważają astronomowie - Księżyc orbitował o około 13 procent bliżej Ziemi. W tamtym czasie tarcza Księżyca przeważała nad tarczą Słońca, ukazując na krótką chwilę tylko niewielki fragment chromosfery Słońca na początku i końcu całkowitego zaćmienia. Gonzalez i Richards nazywają takie zjawiska „super-zaćmieniami”. Dziś możemy natomiast oglądać „zaćmienia doskonałe", w których tarcza Księżyca ledwie zakrywa fotosferę Słońca, a jego chromosfera i korona są widoczne na całym obwodzie i wystarczająco długo, by dało się poczynić użyteczne dla nauki obserwacje. Fakt ten przemawia za tym, że również umiejscowienie w czasie jest istotne dla korelacji między zamieszkiwalnością a mierzalnością. W układzie Ziemia-Księżyc-Słońce doskonałe zaćmienia słoneczne występują akurat wtedy, gdy na Ziemi istnieją organizmy,

\footnotetext{
${ }^{37}$ Por. Gonzalez and Richards, The Privileged Planet..., s. 4-7.
} 
które potrafią zrobić z nich użytek naukowy. ${ }^{38}$ Innym ciekawym zbiegiem okoliczności jest też między innymi to, że w Układzie Słonecznym takie zaćmienia można obserwować tylko z Ziemi, zaś Księżyc i Słońce to dwa najokrąglejsze ciała niebieskie, które znajdują się obecnie w takiej odległości od siebie, że na ziemskim niebie wydają się mieć równą wielkość. ${ }^{39}$

Jak piszą Gonzalez i Richards, zaćmienia słoneczne odegrały ważną rolę w rozwoju nauki, objawiając naturę gwiazd (zaćmienia okazały się pomocne w interpretacji widma Słońca, dzięki czemu możliwe stało się interpretowanie widm odległych gwiazd i określanie ich składu chemicznego), pozwalając w naturalny sposób przetestować einsteinowską ogólną teorię względności i przyspieszając jej akceptację (w 1919 roku astrofizyk Arthur Eddington obserwacyjnie potwierdził przewidywanie tej teorii, że grawitacja zakrzywia światło, co potwierdzały również kolejne obserwacje zaćmień), a także zmierzyć spowolnienie okresu obrotu Ziemi w historii istnienia naszej planety (możliwe jest to dzięki analizie historycznych opisów całkowitych zaćmień słonecznych, które pomagają ustalić odchylenia od przewidywanych lokalizacji geograficznych, w których zaćmienia miały być obserwowane zgodnie z oczekiwaniami, co przekłada się następnie na odchylenia w czasie, wskazujące na zmienność okresu obrotu Ziemi). Co więcej, jak przekonują Gonzalez i Richards, zaćmienia słoneczne przyczyniły się przecież do dostrzeżenia korelacji między zamieszkiwalnością a mierzalnością. ${ }^{40}$

Korelacja między zamieszkiwalnością a mierzalnością jest czymś niespodziewanym w świetle zasady kopernikańskiej, w ramach której stanowi ona kłopotliwą, wymagającą uzasadnienia anomalię, prowadząc do jałowych rozważań teoretycznych. W opinii Gonzaleza i Richardsa korelacja ta ma za to doskonały

\footnotetext{
${ }^{38}$ Ponieważ Księżyc wciąż oddala się od Ziemi, a Słońce zwiększa swój rozmiar, za 250 milionów lat nie będzie już można oglądać doskonałych zaćmień słonecznych z Ziemi. Jak wskazują Gonzalez i Richards, 250 milionów lat to „zaledwie 5 procent wieku Ziemi. To względnie małe okienko możliwości zbiega się również z istnieniem inteligentnego życia. Innymi słowy, najbardziej zamieszkiwalne miejsce w Układzie Słonecznym gwarantuje najlepszą perspektywę do obserwowania zaćmien słonecznych właśnie wtedy, gdy obserwatorzy mogą je najbardziej docenić" (Gonzalez and Richards, The Privileged Planet..., s. 18).

${ }^{39}$ Por. Gonzalez and Richards, The Privileged Planet..., s. 7-10.

${ }^{40}$ Por. Gonzalez and Richards, The Privileged Planet..., s. 10-19.
} 
sens z punktu widzenia teorii inteligentnego projektu, z której wypływa jako naturalna konsekwencja. ${ }^{41}$ Liczne świadectwa, potwierdzające tę korelację, utwierdzają ich w przekonaniu, że „Wszechświat, czymkolwiek jest, zostat zaprojektowany do dokonywania odkryć". ${ }^{42}$ Warto zauważyć, że według nich samo subtelne zestrojenie warunków dla zaistnienia inteligentnego życia nie stanowi tak mocnego świadectwa na rzecz projektu, jak połączenie zamieszkiwalności z możliwością odkryć naukowych. ${ }^{43}$ Jak ujmuje to teoretyk projektu Thomas Woodward: „Gdyby subtelne zestrojenie było zdarzeniem wyłącznie przypadkowym [...] można by za jego pomocą wyjaśnić subtelne zestrojenie prowadzące do powstania inteligentnego życia. Ale prawo i przypadek nie wyjaśniłyby dodatkowego, nieuzasadnionego i zbędnego z punktu widzenia przeżywalności subtelnego zestrojenia, umożliwiającego dokonywanie odkryć naukowych. Ten nowy, znacznie bardziej szokujący wymiar subtelnego zestrojenia sugeruje istnienie umysłu, mistrzowskiego projektanta, zainteresowanego czymś więcej niż tylko rozkwitem życia. Ów projektant najwyraźniej tak zaplanował i uporządkował przyrodę i Ziemię, by umożliwić odkrycia naukowe". ${ }^{44}$

\section{Krytycznym okiem o obecnym stanie badań teorii inteligentnego projektu}

Przejdźmy teraz do rozważenia zarzutu, że teoria inteligentnego projektu jest bezużyteczna dla nauki. Chociaż z perspektywy metodologicznej opracowanie programu badawczego przez teoretyków projektu nie jest niezbędne (wykryć projekt można bowiem nawet wówczas, jeśli nie da się prowadzić dalszych ba-

\footnotetext{
${ }^{41}$ Por. Gonzalez and Richards, The Privileged Planet..., s. 305, 333.

${ }^{42}$ Gonzalez and Richards, The Privileged Planet..., s. 311 [wyróżnienia w oryginale].

${ }^{43}$ Por. Gonzalez and Richards, The Privileged Planet..., s. 304-306.

${ }^{44}$ Woodward, Darwin Strikes Back..., s. 164. Z argumentem Gonzaleza i Richardsa można też zapoznać się w języku polskim: Jay W. Richards, „Dlaczego tu jesteśmy? Przypadek czy cel?”, w: H. Wayne House (red.), Inteligentny projekt 101. Znani eksperci wyjaśniają kluczowe zagadnienia, przeł. Mariusz Cybula, Wydawnictwo Wista, Warszawa 2009, s. 105-124; Lee Stroвel, Dochodzenie w sprawie Stwórcy. Dziennikarz bada dowody naukowe przemawiające za istnieniem Boga, przeł. Józef Kajfosz, Wydawnictwo Credo, Katowice 2007, s. 205-253.
} 
dań na jego temat ${ }^{45}$ ), to realnie patrząc, ewentualny naukowy sukces teorii inteligentnego projektu zależy w dużej mierze od tego, czy zwolennicy tego ujęcia przekonają naukowców, że w jego ramach będą mogli coś robić, że może być ono dobrym, płodnym przewodnikiem badań. Jak pisze jeden z teoretyków projektu — Jay Richards:

Nie wygraliśmy wojny, podobnie jak nie wygrali jej alianci, dokonując inwazji na Normandię. Przekucie zdobytego przez nas przyczółku w zwycięstwo wymaga jeszcze ogromnych zasobów i intelektualnej pracy. I nie chodzi tylko o rozgłos, choć i on jest potrzebny. Teoretycy ID muszą prowadzić kreatywne i wnikliwe badania na gruncie nauk przyrodniczych.

W istocie przyszły sukces teorii inteligentnego projektu zależy, przynajmniej częściowo, od tego, czy zachęca ona do prowadzenia badań i określa ich kierunek. ${ }^{46}$

\section{Podobnie wyraża się teoretyk projektu Jonathan Wells:}

Nowy paradygmat odnosi sukces tylko wtedy, jeśli prowadzi do nowych badań. Istnieją dwa sposoby, na jakie ID może kierować badaniami naukowymi. Po pierwsze, może sugerować teoretyczne i eksperymentalne testy w celu ustalenia, czy pewne zjawiska lepiej da się wyjaśnić inteligentnym projektem, czy darwinowską ewolucją. Po drugie, może służyć za podstawę nowych, testowalnych hipotez, których nie należy raczej spodziewać się po perspektywie darwinowskiej. ${ }^{47}$

\footnotetext{
${ }^{45}$ Taka sytuacja zachodzi również w przypadku aktywności ludzkiej i jej wytworów. Naukowcy do tej pory nie są pewni na przykład, w jakim właściwie celu i jak dokładnie zbudowano Stonehenge lub wytworzono kamienne kule z Kostaryki. Nie posiadając zbyt wielu dodatkowych informacji (co może się nigdy nie zmienić), mogą na ten temat snuć jedynie mniej lub bardziej wiarygodne spekulacje, a jednak wniosek, że te obiekty zostały zaprojektowane, wydaje się niepodważalny (por. Jesse Hicks, „Probing Question: How and Why Was Stonehenge Built?”, Physorg.com 18 March 2010, http://www.physorg.com/news188147461.html [30.03.2010]; William UnderhILL, „Stonehenge odkrywane na nowo”, Świat Nauki 2011, nr 4 (236), s. 46-51; „Researchers Investigate Mysterious Stone Spheres in Costa Rica”, Physorg.com 22 March 2010, http://www.physorg.com/news188485520.html [30.03.2010]). Często podobnie jest w kryminalistyce, kiedy można na przykład ustalić, że doszło do zabójstwa, ale sprawca i motywy jego działania pozostają nieznane.

${ }^{46}$ Jay W. Richards, „Reality \& Reluctant Science: Old Science Confront a Formidable Challenge in the ID Movement”, Touchstone July-August 2004, http://www.touchstonemag.com/archi ves/article.php?id=17-06-046-f $(02.04 .2010)$.

${ }^{47}$ Wells, The Politically Incorrect Guide..., s. 203.
} 
Okazuje się, że wcale nie jest to takie łatwe zadanie i sami teoretycy projektu niejednokrotnie przedstawiali pesymistyczny obraz swoich dotychczasowych osiągnięć na tym polu. Na przykład w 2004 roku Paul Nelson stwierdził:

Niewątpliwie największym wyzwaniem dla społeczności ID jest sformułowanie w pełni rozwiniętej teorii projektu biologicznego. Na dzień dzisiejszy nie dysponujemy taką teorią, a to jest poważny problem. Bez teorii niezmiernie trudno określić, na czym powinny skupić się badania. Jak dotąd, mamy sporo silnych intuicji i garść pojęć, takich jak ,nieredukowalna złożoność” i „,wyspecyfikowana złożoność” - ale nie dysponujemy ogólną teorią projektu biologicznego. ${ }^{48}$

Porównajmy też podobną wypowiedź teoretyka projektu Phillipa Johnsona z 2006 roku:

Ja również nie sądzę, by naprawdę istniała aktualnie teoria inteligentnego projektu mogąca stanowić porównywalną alternatywę dla teorii Darwina, która - mimo swoich mankamentów - jest w pełni dopracowanym programem badawczym. Nie dysponujemy porównywalną teorią inteligentnego projektu. Opracowanie pozytywnej teorii to zadanie naukowców, którzy przyłączyli się do naszego ruchu. Część z nich jest przekonana, że jest to wykonalne, ale to do nich należy udowodnienie tego... ${ }^{49}$

Mimo tych pesymistycznych opinii i mimo tego, że teoretycy projektu rzeczywiście nie prowadzili do tej pory zbyt intensywnych badań (zdecydowana większość intelektualnego dorobku teoretyków projektu ma związek z teoretycznymi, filozoficznymi i metodologicznymi aspektami ich teorii oraz popularyzacją wcześniejszych ustaleń, co niewątpliwie stanowi słaby punkt tej teorii, który może przyczynić się do tego, że nie pozyska ona zbyt wielu nowych zwolenników, a może nawet straci dotychczasowych), lecz przeważnie podpierali swoją teorię wynikami badań uzyskanymi przez naukowców niebędących jej zwolennikami, wskazują oni pewne kierunki badań, zarówno eksperymentalnych, jak i teoretycznych, jakie może inspirować teoria inteligentnego projektu.

\footnotetext{
${ }^{48}$ Jed Macosko and Paul Nelson, „The Measure of Design: A Conversation About the Past, Present \& Future of Darwinism \& Design”, Touchstone July-August 2004, http://www.touchstone mag.com/archives/article.php?id=17-06-060-i (02.04.2010).

${ }^{49}$ Michelangelo D’Agostino, „In the Matter of Berkeley v. Berkeley”, Berkeley Science Review Spring 2006, s. 33 [31-35], http://sciencereview.berkeley.edu/articles/issue10/evolution.pdf (17.03.2009).
} 
Zanim przejdę do przedstawienia tych propozycji, należy zwrócić uwagę, że poszczególne kierunki badawcze mogą zależeć od konkretnych, często sprzecznych ze sobą hipotez, możliwych do sformułowania w ramach ogólnie rozumianej teorii inteligentnego projektu, bowiem koncepcja ta, rozumiana w wąskim sensie jako metoda wykrywania projektu, nie określa jednoznacznie historii wprowadzenia projektu do świata przyrody, ale może być rozmaitymi historiami uzupełniona. Te konkretne historie prowadzą z kolei do mniej lub bardziej ścisłych przewidywań, sugerując określone możliwości badań. Należy mieć też na uwadze, że nie wszystkie te kierunki badań muszą być inspirowane wyłącznie przez teorię inteligentnego projektu.

Warto też wspomnieć, że od 2005 roku działa założony przez teoretyków projektu Biologic Institute (http://biologicinstitute.org) z siedzibą w Redmont w stanie Waszyngton. Celem instytutu jest ,rozwijanie i testowanie naukowej argumentacji na rzecz inteligentnego projektu w biologii oraz badanie jej naukowych implikacji”. ${ }^{50} \mathrm{Cel}$ ten członkowie Biologic Institute chcą realizować, wykorzystując wiedzę technologiczną zwłaszcza w badaniach nad światem biologicznym (a dotychczas było zwykle na odwrót), przy czym zagadnienie to ma być rozpatrywane „z każdej strony - eksperymentalnej, obliczeniowej i teoretycznej — jak również w każdej skali, od molekularnej po galaktyczną". ${ }^{51}$ Dlatego instytut skupia badaczy z wielu różnych dyscyplin, takich jak biologia molekularna, biofizyka, biologia, biochemia, bioinformatyka, genomika, astrobiologia, inżynieria i informatyka. Dyrektorem Biologic Institute jest biolog molekularny Douglas Axe, specjalizujący się w badaniach nad pochodzeniem oraz ewolucją białek i układów białkowych, ze szczególnym uwzględnieniem funkcjonalnych i strukturalnych ograniczeń procesów ewolucyjnych.

Obszary badań zespołu z Biologic Institute obejmują takie zagadnienia jak pochodzenie i rola informacji w biologii, fizyczne warunki umożliwiające istnienie życia, warunki potrzebne, by powstanie różnych form życia było prawdopodobne, a także schematy projektowe i charakterystyczne cechy wytworów zaprojektowanych. ${ }^{52}$

\footnotetext{
${ }^{50}$ Biologic Institute, ,About”, http://biologicinstitute.org/about/ (30.04.2009).

${ }^{51} \mathrm{http}$ ///biologicinstitute.org/ (30.04.2009).

${ }^{52}$ Por. Biologic Institute, „Research”, http://biologicinstitute.org/research/ (30.04.2009).
} 
Temat Biologic Institute poruszono na łamach New Scientist w artykule wskazującym między innymi, że powstanie instytutu to w gruncie rzeczy odpowiedź na wynik procesu sądowego w Dover, ${ }^{53}$ który ukazał według autorki „najpoważniejszą słabość ID”. Przytacza ona przy tej okazji słowa Richarda Olmsteada - biologa z University of Washington w Seattle: „Zgodnie z krytyką, kierowaną pod ich [teoretyków projektu] adresem, najczęściej mówią oni o nauce, ale jej nie uprawiają". Działalność Biologic Institute miałaby to zmienić. Niektórzy komentatorzy uważają, że miałoby to bardziej wymiar polityczny niż naukowy, pomocny w wywieraniu wpływu na edukację publiczną. Natomiast Ronald Numbers, znany i szanowany historyk ruchu kreacjonistycznego, postrzega Biologic Institute jako przedsięwzięcie, którego celem jest podtrzymanie poparcia dla teorii inteligentnego projektu wśród jej dotychczasowych zwolenników: „Byłoby czymś dobrym z punktu widzenia szeregowych żołnierzy ruchu ID, gdyby jego przywódcy mogli powiedzieć: my nie tylko teoretyzujemy. Mamy laboratoria i prawdziwych naukowców, którzy nad tym pracują". ${ }^{54}$

W 2010 roku badacze związani z Biologic Institute zaczęli wydawać także sprawiające wrażenie profesjonalnego, recenzowane czasopismo naukowe, poświęcone problemom znajdującym się w obszarze zainteresowań teorii inteligentnego projektu - BIO-Complexity (www.bio-complexity.org). W zamyśle czasopismo to ma być „głównym forum dla testowania naukowej wartości twierdzenia, że teoria inteligentnego projektu (ID) jest wiarygodnym wyjaśnieniem życia", zaś najważniejszym zagadnieniem poruszanym na jego łamach jest „rola i pochodzenie informacji w układach ożywionych”. ${ }^{55}$ Rozwój czasopisma

${ }^{53}$ Miał on miejsce w 2005 roku. Był to pierwszy i jak dotąd jedyny proces sądowy, który bezpośrednio dotyczył kwestii konstytucyjności ewentualnego wprowadzenia teorii inteligentnego projektu do programu nauczania w amerykańskich szkołach publicznych.

${ }^{54}$ Celeste BIEver, „Intelligent Design: The God Lab”, New Scientist 2006, no. 2582, s. 8-11, http://www.newscientist.com/article/mg19225824.000-intelligent-design-the-god-lab.html?full=tr ue (01.05.2009). Por. też National Center for Science Education, „New Scientist Visits the «God Lab»", 15 December 2006, http://ncse.com/news/2006/12/new-scientistem-visits-god-lab-00940 (01.05.2009); Marcin RoткіEwicz, „Wiara i szkiełko”, Polityka 10 lutego 2007, nr 6 (2591), s. 82, http://archiwum.polityka.pl/art/wiara-i-szkielko,362063.html (01.05.2009); John G. WEst, „Intelligent Design Research Lab Highlighted in New Scientist", Evolution News \& Views 19 December 2006, http://www.evolutionnews.org/2006/12/intelligent_design_research_la.html (01.05.2009).

${ }^{55}$ BIO-Complexity, „Editorial Policies”, http://bio-complexity.org/ojs/index.php/main/about/ editorialPolicies (01.05.2010). Por. też Douglas D. AxE, „The Debate Over Design Gains Momen- 
BIO-Complexity może, choć nie musi, w przyszłości zmienić nastawienie do badawczego i publikacyjnego zaplecza teorii inteligentnego projektu. ${ }^{56}$

\section{Możliwe badania w ramach teorii inteligentnego projektu}

Najbardziej oczywistym, jak się wydaje, przedmiotem badań zwolenników teorii inteligentnego projektu jest poszukiwanie biologicznych układów (i to na różnych poziomach organizacji — molekularnym, fizjologicznym czy anato-

tum with a New Peer-Reviewed Science Journal: BIO-Complexity", Biologic Institute 30 April 2010, http://biologicinstitute.org/2010/04/30/the-debate-over-design-gains-momentum-with-a-new-peer-rev iewed-science-journal-bio-complexity/ (01.05.2010).

${ }^{56}$ Do tej pory (sierpień 2013) na łamach tego czasopisma ukazało się 14 publikacji: Douglas D. Axe, „The Case Against a Darwinian Origin of Protein Folds”, BIO-Complexity 2010 , no. 1, s. 1-12, http://bio-complexity.org/ojs/index.php/main/article/view/BIO-C.2010.1/BIO-C.20 10.1 (07.02.2013); Ann K. Gauger, Stephanie Ebnet, Pamela F. Fahey, and Ralph Seelke, „Reductive Evolution Can Prevent Populations from Taking Simple Adaptive Paths to High Fitness", BIO-Complexity 2010, no. 2, s. 1-9, http://bio-complexity.org/ojs/index.php/main/article/view/ BIO-C.2010.2/BIO-C.2010.2 (07.02.2013); George MontaÑez, Winston Ewert, William A. DemBSKI, and Robert J. MARKS II, „A Vivisection of the ev Computer Organism: Identifying Sources of Active Information”, BIO-Complexity 2010, no. 3, s. 1-6; http://bio-complexity.org/ojs/index.php/ main/article/view/BIO-C.2010.3/BIO-C.2010.3 (07.02.2013); Douglas D. Axe, „The Limits of Complex Adaptation: An Analysis Based on a Simple Model of Structured Bacterial Populations", BIO-Complexity 2010, no. 4, s. 1-10, http://bio-complexity.org/ojs/index.php/main/ar ticle/view/BIO-C.2010.4/BIO-C.2010.4 (07.02.2013); Ann K. Gauger and Douglas D. AXe, „The Evolutionary Accessibility of New Enzymes Functions: A Case Study from the Biotin Pathway”, BIO-Complexity 2011, no. 1, s. 1-17, http://bio-complexity.org/ojs/index.php/main/article/view/BI O-C.2011.1/BIO-C.2011.1 (07.02.2013); Stephen C. MeYer and Paul A. Nelson, „Can the Origin of the Genetic Code Be Explained by Direct RNA Templating?", BIO-Complexity 2011, no. 2, s. 1-10, http://bio-complexity.org/ojs/index.php/main/article/view/BIO-C.2011.2/BIO-C.2011.2 (07.02.2013); Douglas D. Axe, Philip Lu, and Stephanie Flatau, „A Stylus-Generated Artificial Genome with Analogy to Minimal Bacterial Genomes”, BIO-Complexity 2011, no. 3, s. 1-15, http ://bio-complexity.org/ojs/index.php/main/article/view/BIO-C.2011.3/BIO-C.2011.3 (07.02.2013); Winston Ewert, William A. Dembski, and Robert J. Marks II, „Climbing the Steiner Tree Sources of Active Information in a Genetic Algorithm for Solving the Euclidean Steiner Tree Problem”, BIO-Complexity 2012, no. 1, s. 1-14, http://bio-complexity.org/ojs/index.php/main/arti cle/view/BIO-C.2012.1/BIO-C.2012.1 (07.02.2013); Fernando Castro-Chavez, „A Tetrahedral Representation of the Genetic Code Emphasizing Aspects of Symmetry", BIO-Complexity 2012, no. 2, s. 1-6, http://bio-complexity.org/ojs/index.php/main/article/view/BIO-C.2012.2/BIO-C.201 2.2 (07.02.2013); Matti Leisola, Ossi Pastinen, and Douglas D. Axe, „Lignin - Designed Randomness", BIO-Complexity 2012, no. 3, s. 1-11, http://bio-complexity.org/ojs/index.php/main/ar ticle/view/BIO-C.2012.3/BIO-C.2012.3 (07.02.2013); Winston Ewert, William A. Dembski, Ann K. Gauger, and Robert J. Marks II, „Time and Information in Evolution”, BIO-Complexity 2012, 
micznym), które charakteryzowałyby się nieredukowalną bądź wyspecyfikowaną złożonością. Badania $\mathrm{w}$ tym zakresie mogą obejmować również zagadnienie minimalnej złożoności, jaką musi mieć organizm, aby mógł w ogóle egzystować i rozmnażać się. Ustalenie, czy dany system jest nieredukowalnie złożony w sensie niemożliwości usunięcia z niego jakichś składników bez utraty funkcji układu, może mieć charakter ściśle eksperymentalny. Badacze znają technikę, która może do tego celu posłużyć; jest to mianowicie tak zwana technika „nokautowania" genów, polegająca na wyłączaniu czy wyciszaniu aktywnych genów w genomie organizmów przy wykorzystaniu narzędzi inżynierii genetycznej. Na podstawie takich badań można stworzyć katalog tego typu układów, obejmujący szczegółowe dane i opisy. Im w przyrodzie więcej układów o nieredukowalnej i wyspecyfikowanej złożoności i w im głębsze poziomy życia sięgają, tym większy kłopot dla wyjaśnień naturalistycznych i lepsze podstawy dla wniosku o projekcie — przyjmując, rzecz jasna, że nieredukowalna i wyspecyfikowana złożoność są wiarygodnymi znamionami projektu. Jednym z głównych zadań teoretyków projektu może być też opracowywanie lub dopracowywanie konkretnych metod wykrywania oraz poszukiwanie ewentualnych nowych kryteriów projektu. W ramach fizyki i kosmologii mogą natomiast poszukiwać nowych przykładów subtelnego zestrojenia praw i stałych fizycznych dla możliwości istnienia życia oraz - co związane jest $\mathrm{z}$ argumentem Gonzaleza i Richardsa — korelacji między własnościami umożliwiającymi istnienie inteligentnych istot żywych a tymi, które pozwalają na prowadzenie badań naukowych przez te istoty, czyli korelacji między zamieszkiwalnością a mierzalnością. ${ }^{57}$

no. 4, s. 1-7, http://bio-complexity.org/ojs/index.php/main/article/view/BIO-C.2012.4/BIO-C.201 2.4 (07.02.2013); Michael J. Denton, ,The Place of Life and Man in Nature: Defending the Anthropocentric Thesis", BIO-Complexity 2013, no. 1, s. 1-15, http://bio-complexity.org/ojs/index. php/main/article/view/BIO-C.2013.1/BIO-C.2013.1 (28.02.2013); Granville Sewell, „Entropy and Evolution”, BIO-Complexity 2013, no. 2, s. 1-5, http://bio-complexity.org/ojs/index.php/mai n/article/view/BIO-C.2013.2/BIO-C.2013.2 (27.06.2013); Michael J. Denton, „The Types: A Persistent Structuralist Challenge to Darwinian Pan-Selectionism", BIO-Complexity 2013, no. 3, s. 118, http://bio-complexity.org/ojs/index.php/main/article/view/BIO-C.2013.3/BIO-C.2013.3 (22. 08.2013).

${ }^{57}$ Por. William A. Dembski, „Tematy badań w ramach teorii inteligentnego projektu”, przeł. Dariusz Sagan, Na Początku... 2005, R. 12, nr 3-4 (192-193), s. 137-138 [136-146], http://www. nauka-a-religia.uz.zgora.pl/index.php?action=tekst\&id=71 (04.04.2010); William A. DemBSKI, The Design Revolution: Answering the Toughest Questions about Intelligent Design, InterVarsity Press, Downers Grove, Illinois 2004, s. 311; William A. Dembski, „Becoming a Disci- 
Istotną dla teoretyków projektu sferą badawczą może być z pewnością praca nad tym, co jest raczej negatywnym aspektem ich teorii, to jest znajdowaniem świadectw przeciwko koncepcjom naturalistycznym. Przedmiotem szczególnego zainteresowania jest problem zdolności do ewoluowania czy ewoluowalności. Podczas gdy ewolucjoniści skupiają się na ustalaniu związków między różnymi organizmami, teoretycy projektu mogą obrać inną strategię, dokonując manipulacji na pojedynczych organizmach lub układach biologicznych, zakłócając ich normalne funkcjonowanie i sprawdzając, jakie zmiany ewolucyjne, wspomagane inteligentnym kierownictwem albo nie, mogą w takim wypadku nastąpić. Wszelkie dostrzeżone ograniczenia zdolności ewoluowania można zinterpretować na korzyść teorii inteligentnego projektu. ${ }^{58}$ Często uważa się, że krytyka nie stanowi pozytywnego wkładu w wiedzę. Zważywszy jednak, że mamy tu do czynienia $\mathrm{z}$ dychotomią: albo układy biologiczne powstały bez udziału inteligencji, albo przy jej pomocy - to nawet gdyby nie znajdowano charakterystycznych oznak inteligencji w układach biochemicznych, odrzucenie wszystkich możliwych teorii naturalistycznych pozostawiłoby projekt jako jedyną alternatywę, zaś (co jest bardziej realistyczne) obalanie coraz to nowych scenariuszy naturalistycznych w pewnym sensie przybliżałoby akceptację hipotezy projektu. Wykazanie, że układy biologiczne mają ograniczoną zdolność do ewoluowania (zauważmy, że nie jest to zwykłe wykazywanie błędności konkretnych wyjaśnień ewolucjonistycznych), można w pewnym sensie uznać za wkład pozytywny, podobnie jak jest na przykład wtedy, gdy stwierdzamy, że wytwory

plined Science: Prospects, Pitfalls, and Reality Check for ID”, Design Inference 22 October 2002, http://www.designinference.com/documents/2002.10.27.Disciplined_Science.htm (03.05.2009); IDEA Center, „FAQ: Wouldn't Intelligent Design Theory Be the End of Scientific Investigation — a Science Stopper?", http://www.ideacenter.org/contentmgr/showdetails.php/id/1181 (08.04. 2010); IDEA Center, „FAQ: What Sort of Progress Has Intelligent Design Made Recently?”, http: //www.ideacenter.org/contentmgr/showdetails.php/id/1180 (08.04.2010); Wolf-Ekkehard LöNNIG, „Dynamic Genomes, Morphological Stasis, and the Origin of Irreducible Complexity”, Dynamical Genetics 2004, s. 113-115 [101-119], http://www.weloennig.de/DynamicGenomes.pdf (11.04. 2010).

${ }^{58}$ Por. Dembski, „Tematy badań...”, s. 138; Dembski, The Design Revolution..., s. 311-312; Dembsкi, „Becoming a Disciplined Science...”; IDEA Center, „FAQ: Wouldn’t Intelligent Design...”; IDEA Center, „FAQ: What Sort of Progress...”; LöNNIG, „Dynamic Genomes...”, s. 113. 
ludzkie, jak komputery czy samochody, nie mogą (pomijając degradację) samoistnie przekształcać się w coś innego. ${ }^{59}$

Do tego typu badań można zaliczyć eksperymenty wykonane już i nadal przeprowadzane przez Douglasa Axe, szefa Biologic Institute. Wykorzystując technikę mutagenezy, Axe ustalił częstość występowania trwałych, funkcjonalnych białek, liczących 150 aminokwasów, w przestrzeni możliwych konfiguracji struktur białkowych o takiej samej liczbie aminokwasów. Z jego obliczeń wynika, że takie białka występują bardzo rzadko, w przestrzeni konfiguracyjnej stanowią raczej „osamotnione wyspy” niż ciągłe kontinuum, a prawdopodobieństwo przypadkowego utworzenia się choćby jednego takiego białka (dobór nie wchodzi w grę, zanim powstanie funkcjonalne białko) jest niezmiernie małe i wynosi 1 szansę na $10^{74}$ prób. Takie wyniki, o ile są wiarygodne, mogą oczywiście posłużyć jako argument przeciwko naturalistycznym teoriom ewolucji, gdyż wskazują na istnienie dużych luk między strukturami molekularnymi, które niełatwo wypełnić postulowaniem działania niekierowanych procesów naturalnych, a przy okazji może to pośrednio sugerować aktywność inteligencji. ${ }^{60}$ Za podobne, tyle że raczej na gruncie teoretycznym, można uznać przedsięwzięcie Michaela Behe'ego, który poszukuje minimalnej granicy twórczych możliwości procesów darwinowskich, jeśli chodzi o tworzenie nowych funkcjonalnych struktur białkowych, wymagających jednoczesnego wytworzenia kilku nowych białek, przy uwzględnieniu znanego tempa mutacji oraz realistycznych szacunków wielkości populacji i ilości czasu, jakie były dostępne w historii Ziemi. ${ }^{61}$ Innym negatywnym, aczkolwiek nie mniej ważnym, aspektem badań teo-

\footnotetext{
${ }^{59}$ Por. też SAGAN, „Ewaluacja ewolucjonistycznych rozwiązań...”, s. 112.

${ }^{60}$ Por. Meyer, Signature in the Cell..., s. 209-213, 494-495; Douglas D. Axe, „Estimating the Prevalence of Protein Sequences Adopting Functional Enzyme Folds”, Journal of Molecular Biology 2004, vol. 341, s. 1295-1315; Douglas D. AxE, „Extreme Functional Sensitivity to Conservative Amino Acid Changes on Enzyme Exteriors", Journal of Molecular Biology 2000, vol. 301, s. 585-595, http://nsmserver2.fullerton.edu/departments/chemistry/evolution_creation/web/ AxeProteinEvolution.pdf (08.04.2010); AxE, „The Case Against a Darwinian Origin...”; William A. Dembski and Jonathan Wells, The Design of Life: Discovering Signs of Intelligence in Biological Systems, Foundation for Thought and Ethics, Dallas 2008, s. 199-203; Wells, The Politically Incorrect Guide..., s. 204.
}

${ }^{61}$ Por. Michael J. Behe, The Edge of Evolution: The Search for the Limits of Darwinism, The Free Press, New York 2007; Michael J. Behe and David W. Snoke, „Simulating Evolution by 
retyków projektu jest też krytyka wyników eksperymentów ewolucyjnych, które postrzegane są przez ewolucjonistów jako „dowody ewolucji w działaniu”. ${ }^{62}$

Jako że powstanie życia oraz bardziej złożonych jego form można utożsamiać z tworzeniem nowej informacji, teoretycy projektu mogą też prowadzić teoretyczne dociekania na temat natury informacji, jak również teoretyczno-empiryczne badania nad zdolnością ślepych procesów naturalnych do tworzenia nowej informacji oraz przetwarzania i przekazywania informacji już istniejącej. Badania te mają związek z postulowanym przez Williama Dembskiego prawem zachowania informacji, zgodnie z którym złożona wyspecyfikowana informacja nie może powstać w układach zamkniętych bez udziału zewnętrznego czynnika inteligentnego. W tym względzie teoretycy projektu mogą poddawać analizie opracowywane przez ewolucjonistów algorytmy genetyczne, mające na celu symulację tworzenia nowej informacji przez niekierowane procesy ewolucyjne. Mogą wykazywać, że algorytmy te nie tworzą nowej informacji, gdyż w istocie została ona w którymś punkcie ,przemycona” do algorytmu przez programistów. Tematem tym zajmują się już teoretycy projektu związani z The Evolutionary Informatics Lab, zwłaszcza William Dembski i Robert Marks. ${ }^{63}$

Gene Duplication of Protein Features That Require Multiple Amino Acid Residues”, Protein Science 2004, vol. 13, s. 2651-2664, http://www3.interscience.wiley.com/cgi-bin/fulltext/121602290 /PDFSTART (17.03.2010); Michael J. BEHE, „Blind Evolution or Intelligent Design?: Address to the American Museum of Natural History", American Museum of Natural History 23 April 2002, http://www.discovery.org/a/1205 (24.08.2009); Wells, The Politically Incorrect Guide..., s. 204.

${ }^{62}$ Por. Michael J. BehE, „Experimental Evolution, Loss-of-Function Mutations, and «the First Rule of Adaptive Evolution»", The Quarterly Review of Biology 2010, vol. 85, no. 4, s. 419-445.

${ }^{63}$ Por. np. William A. Dembski and Robert J. Marks II, „Conservation of Information in Search: Measuring the Cost of Success", IEEE Transactions on Systems, Man and Cybernetics Part A: Systems and Humans 2009, vol. 39, no. 5, s. 1051-1061, http://evoinfo.org/papers/2009 ConservationOfInformationInSearch.pdf (09.04.2010); William A. DemBSKI and Robert J. MarKS II, „Bernoulli's Principle of Insufficient Reason and Conservation of Information in Computer Search", Proceedings of the 2009 IEEE International Conference on Systems, Man, and Cybernetics 2009, s. 2647-2652, http://evoinfo.org/papers/2009_BernoullisPrinciple.pdf (09.04.2010); Winston Ewert, William A. Dembski and Robert J. Marks II, „Evolutionary Synthesis of Nand Logic: Dissecting the Digital Organism", Proceedings of the 2009 IEEE International Conference on Systems, Man, and Cybernetics 2009, s. 3047-3053, http://evoinfo.org/papers/2009_Evo lutionarySynthesis.pdf (09.04.2010); William A. Dembski and Robert J. Marks II, „Life's Conservation Law: Why Darwinian Evolution Cannot Create Biological Information”, w: Bruce L. GoRDON and William A. Dembski (eds.), Nature of Nature: Examining the Role of Naturalism in Science, ISI Books, Wilmington, Delaware 2011, s. 360-399, http://evoinfo.org/papers/ConsInfo_No 
Różne wersje teorii inteligentnego projektu - monofiletyczna (pochodzenie wszystkich organizmów od jednego przodka) i polifiletyczna (pochodzenie różnych grup organizmów od innych przodków) - dostarczają odmiennego spojrzenia na historię życia. Jednym z problemów badawczych dla teoretyków projektu może być więc próba rozstrzygnięcia między tymi koncepcjami, choćby poprzez analizy filogenetyczne, które mogą prowadzić albo do wniosku, że istnieje jedno wspólne drzewo, albo wiele drzew lub las życia. Niebagatelne znaczenie w tym zakresie ma konstruowanie schematów historii życia na podstawie świadectw paleontologicznych: czy znajdowane skamieniałości układają się we wzorzec stopniowych przekształceń, czy też ukazują raczej nagłe pojawianie się nowych, w pełni ukształtowanych organizmów i długie ich trwanie w niemal niezmienionej postaci? W tym kontekście rodzą się kolejne problemy teoretyczne, dotyczące sposobu realizacji projektu. Jeżeli między organizmami istnieje ciągłość, to czy rozwój życia mógł zostać tak zaprogramowany, że wystarczyło jedynie uruchomić program, po czym nie była potrzebna żadna dodatkowa interwencja projektanta, a zachodziła po prostu stopniowa, choć zaprojektowana, ewolucja? A jeśli organizmy oddzielone są lukami, wskazującymi na duże skoki informacyjne, to czy projektant musiał aktywnie wprowadzać nowe informacje, jak to jest w przypadku ewolucji technologicznej, dokonywanej przez ludzi, czy też i w tej sytuacji mógł zaprogramować cały, nieciągły rozwój życia od samego początku? ${ }^{64}$

Podczas gdy wersje teorii inteligentnego projektu, postulujące zaprogramowany projekt, mogą dopuszczać istnienie narządów szczątkowych (szczególnie chodzi o niefunkcjonalne, bo mogą być też funkcjonalne narządy szczątkowe) i dużych ilości „śmieciowego” DNA (DNA niekodującego białek lub innych funkcjonalnych elementów) czy pseudogenów (niedziałających kopii genu),

N.pdf (09.04.2010); Ewert, Dembski, and Marks II, „A Vivisection of the ev Computer Organism...”; Ewert, Dembski, Gauger, and Marks II, „Time and Information in Evolution...”. Por. też Meyer, Signature in the Cell..., s. 483-484; DembSki, „Tematy badań...”, s. 137, 141-142; DembSKI, The Design Revolution..., s. 311, 314; DemBSKI, „Becoming a Disciplined Science...”; IDEA Center, „FAQ: Wouldn't Intelligent Design...”; IDEA Center, „FAQ: What Sort of Progress...”.

${ }^{64}$ Por. Meyer, Signature in the Cell..., s. 487-490; Dembski, „Tematy badań...”, s. 139-141; Dembsкi, The Design Revolution..., s. 312-313; Dembsкi, „Becoming a Disciplined Science...”; IDEA Center, „FAQ: Wouldn't Intelligent Design...”; IDEA Center, „FAQ: What Sort of Progress...". 
gdyż można je uznać za efekt uboczny działania procesów naturalnych, nie wszystkie wersje mówiące o interwencjach projektanta pozwalają na to. W zasadzie dla ogólnie pojmowanej teorii inteligentnego projektu byłoby lepiej, gdyby takie cechy były rzadkością w świecie biologii. Dlatego, w przeciwieństwie do darwinizmu, teoria ta (a zwłaszcza niektóre jej wersje) zachęca do poszukiwania funkcji struktur biologicznych sprawiających wrażenie bezużytecznych pozostałości działania ślepych procesów przyrodniczych. W odniesieniu do zagadnienia „śmieciowego" DNA polski kreacjonista i zwolennik teorii inteligentnego projektu Mieczysław Pajewski uznaje wręcz, że jest ona w tym metodologicznym względzie lepsza od darwinizmu: „,[...] zarzut, jaki ewolucjoniści stawiają kreacjonistom, dotyczący niebezpieczeństwa hamowania rozwoju nauki, można [...] postawić także ewolucjonistom. Jeśli bowiem uczeni nie znają funkcji sporej części materiału genetycznego, to teoria ewolucji może ich skłaniać do zaniechania prób znalezienia takiej funkcji i do uznania, że mają do czynienia ze «śmieciowym DNA» [...]. Tu akurat kreacjonizm ujawnia swoją metodologiczną wyższość, bowiem jeśli życie zostało zaplanowane przez inteligentnego projektanta, to prawdopodobnie cały materiał genetyczny albo przynajmniej duża jego część musi mieć biologiczny sens i należy go poszukiwać”. ${ }^{65}$

Ewentualnie, jeśli pewne struktury biologiczne rzeczywiście nie pełnią żadnych funkcji, można sprawdzić, czy da się znaleźć jakieś potwierdzenie tezy, że pierwotnie były to funkcjonalne projekty, ale uległy degeneracji w wyniku aktywności procesów naturalnych. O degeneracji projektu można mówić także w kontekście struktur czy organizmów uznawanych przez ludzi za złe w kategoriach moralnych, na przykład bakterii i ich maszynerii służącej do wstrzykiwania toksyn innym organizmom. Równie ważne z punktu widzenia teoretyków projektu może być poszukiwanie zalet $\mathrm{w}$ budowie i funkcjonowaniu struktur, które na pierwszy rzut oka wyglądają na nieudolne czy suboptymalne rozwiązania, albo - z drugiej strony — znajdowanie rozwiązań optymalnych lub bliskich optymalności. ${ }^{66}$

\footnotetext{
${ }^{65}$ Mieczysław PAJewski, „Płodność poznawcza kreacjonizmu”, Na Poczatku... 2003, R. 11, nr 7-8 (170-171), s. 273-274 [272-275].

${ }^{66}$ Por. Meyer, Signature in the Cell..., s. 490-491; Dembski, „Powrót projektu...”, s. 22-23; Dembski, „Tematy badań...”, s. 141; Dembsкi, The Design Revolution..., s. 313; Dembski, „Becoming a Disciplined Science...”; IDEA Center, „FAQ: Wouldn’t Intelligent Design...”;
} 
W ramach teorii inteligentnego projektu sprawdzeniu podlegać mogą konkretne hipotezy, inspirowane dyskusjami między teoretykami projektu a ewolucjonistami na temat postulowanych przypadków układów biologicznych o nieredukowalnej lub wyspecyfikowanej złożoności. Ewolucjoniści twierdzą na przykład, że wić bakteryjna, uznawana przez Michaela Behe’ego za układ nieredukowalnie złożony, wyewoluowała z prostszej struktury bakteryjnej - aparatu wydzielinowego typu III, służącego do wstrzykiwania toksyn innym organizmom i składającego się z białek homologicznych do podzbioru białek wici bakteryjnej. Teoretyk projektu Scott Minnich stara się natomiast wykazać i znajduje pewne wskazówki, że układ postrzegany przez ewolucjonistów jako prekursor wici bakteryjnej w istocie powstał od niej później i to najprawdopodobniej w wyniku degeneracji wici, to jest utraty części składającej się na nią informacji biologicznej. ${ }^{67}$

W odróżnieniu od koncepcji naturalistycznych teoria inteligentnego projektu wyraźnie zachęca do badania organizmów żywych oraz ich części z inżynierskiego punktu widzenia, kierując się zasadą regulatywną, nazywaną przez Williama Dembskiego ,inżynieryzmem metodologicznym” (methodological engineering). Analizie inżynierskiej miałyby według Dembskiego podlegać takie kwestie jak ,powstanie, budowa, działanie, uszkodzenie, zużycie, naprawa i —

Michael J. BeHE, „Funkcjonalny pseudogen? List otwarty do Nature”, przeł. Mieczysław Pajewski, Na Poczatku ... 2003, R. 11, nr 7-8 (170-171), s. 276-277; Michael J. Denton, „Inverted Retina: Maladaptation or Pre-Adaptation?", Origins \& Design 1999, vol. 19, no. 2, http://www. arn.org/docs/odesign/od192/invertedretina192.htm (06.05.2010); George AyouB, „O projekcie siatkówki kręgowców”, przeł. Mieczysław Pajewski, Na Początku... 2002, nr 3-4 (153-154), s. 67-68, http://creationism.org.pl/artykuly/GAyoub (06.05.2010); Thomas F. HeInze, „Kto zaprojektował dzięcioła?", http://www.inteligentny-projekt.pl/index.php?option=com_content\&view= article\&id=193\&Itemid=213 (09.04.2010); „Cell Positioning Uses «Good Design»”, Evolution News and Views 2 March 2013, http://www.evolutionnews.org/2013/03/cell_positionin069471.ht $\mathrm{ml}(08.03 .2013)$.

${ }^{67}$ Por. Meyer, Signature in the Cell..., s. 492-494; Scott A. Minnich and Stephen C. Meyer, „Genetic Analysis of Coordinate Flagellar and Type III Regulatory Circuits in Pathogenic Bacteria”, w: Dembski (ed.), Darwin's Nemesis..., s. 214-223, http://www.discovery.org/scripts/view DB/filesDB-download.php?id=389 (27.03.2010); Kitzmiller et al. v. Dover Area School District, 3 November 2005, Day 20, PM Session, s. 1-160, http://ncse.com/files/pub/legal/kitzmiller/trial transcripts/2005_1103_day20_pm.pdf (09.04.2010); Kitzmiller et al. v. Dover Area School District, 4 November 2005, Day 21, AM Session, s. 1-126, http://www.aclupa.org/downloads/Day21 AMSession.pdf (09.04.2010). 
przede wszystkim - historia przekształceń (zarówno zaprojektowanych, jak i przypadkowych)" ${ }^{6}$ układów biologicznych. W ten nurt wpisują się z pewnością badania prowadzone przez Jonathana Wellsa, który stosując rozumowanie inżynierskie, stara się eksperymentalnie przetestować hipotezę, że organelle komórkowe zwane centriolami, tworzące centrosom, strukturę pełniącą znaczącą rolę $\mathrm{w}$ procesie podziału komórkowego, są $\mathrm{w}$ istocie zaprojektowanymi turbinami, zawierającymi struktury przypominające śruby Archimedesa, których dolna część zanurzona jest w cieczy, wypychanej do góry wskutek obrotu śruby. Wells spekuluje, że to wadliwe funkcjonowanie centrioli, nie zaś - jak sugeruje perspektywa darwinowska - mutacje w DNA, może być przyczyną początkowych etapów rozwoju raka. ${ }^{69}$

Dla Wellsa przykładem hipotezy (raczej jednak dość odlegle) inspirowanej teorią inteligentnego projektu jest też hipoteza postawiona przez naukowca-amatora Forresta Mimsa. Ten ostatni badał w Brazylii bakterie unoszące się w powietrzu i stwierdził, że są one wrażliwe na promieniowanie ultrafioletowe, co jest zaskakujące $\mathrm{z}$ darwinowskiego punktu widzenia, jako że zgodnie z nim bakterie już dawno powinny wykształcić odporność na ten powszechnie dostępny na powierzchni ziemskiej rodzaj promieniowania, ale jest spójne $\mathrm{z}$ teorią inteligentnego projektu. ${ }^{70}$ Mims sformułował na tej podstawie przewidywanie, że także wirusy ptasiej grypy są niszczone przez promieniowanie ultrafioletowe,

\footnotetext{
${ }^{68}$ Dembski, „Tematy badań...”, s. 139. Por. też Dembski, The Design Revolution..., s. 312; Dembsкi, „Becoming a Disciplined Science...”.

${ }^{69}$ Por. Jonathan Wells, „Do Centrioles Generate Polar Ejection Force?”, Rivista di Biologia 2005, vol. 98, s. 71-95, http://www.discovery.org/scripts/viewDB/filesDB-download.php?comma nd=download\&id=490 (07.03.2010); Jonathan WeLLS, „Using Intelligent Design Theory to Guide Scientific Research", Progress in Complexity, Information, and Design 2004, vol. 3.1.2, s. 1-14, http://www.iscid.org/papers/Wells_TOPS_051304.pdf (07.03.2010); WelLs, The Politically Incorrect Guide..., s. 205; Jonathan Wells, „A Possible Link Between Centrioles, Calcium Deficiency and Cancer", Discovery Institute, http://www.discovery.org/scripts/viewDB/filesDB-down load.php?command=download\&id=644 (07.03.2010); MeYER, Signature in the Cell..., s. 485487.

${ }^{70}$ Pogląd na relację omawianego zjawiska do darwinizmu i teorii inteligentnego projektu jest przypisywany Mimsowi przez Wellsa (por. Welds, The Politically Incorrect Guide..., s. 204) W publikacji Mimsa, do której odsyła Wells (por. następny przypis), nie ma o tym mowy. Wells nie wyjaśnia też, na czym dokładnie polega spójność tego zjawiska z teorią inteligentnego projektu (Wells pisze wręcz, że Mims uważa je za „świadectwo na rzecz projektu”).
} 
a zatem rozprzestrzenianie się ptasiej grypy można kontrolować poprzez nieograniczanie dawek promieniowania ultrafioletowego, docierających do Ziemi. Mogłoby to mieć szczególne znaczenie w rejonach świata, gdzie pod nowe uprawy sezonowo wypalana jest biomasa, co idzie w parze ze wzrostem zachorowań na ptasią grypę, a czemu można przeciwdziałać — według Mimsa $\mathrm{w}$ dużej mierze dzięki redukcji zadymienia środowiska związanego $\mathrm{z}$ wypalaniem biomasy. ${ }^{71}$

Zwolennicy teorii inteligentnego projektu mogą ponadto skupiać swoje badania nie tylko na poszukiwaniu ogólnych cech sugerujących, że organizmy czy układy biologiczne zostały zaprojektowane przez jakąś istotę inteligentną, lecz także konkretniejszych cech biologicznych, które już same w sobie wydają się niespodziewane z punktu widzenia ujęć naturalistycznych i bardzo kłopotliwe, jeśli chodzi o wyjaśnienie ich w kategoriach ślepych, niekierowanych przyczyn naturalnych.

Stephen Meyer wskazuje na co najmniej trzy takie odkryte już cechy organizmów żywych. Jedna $\mathrm{z}$ nich to gęste upakowanie funkcjonalnej informacji w genomie. Związane jest to przede wszystkim $\mathrm{z}$ odkrywaniem funkcjonalności „śmieciowego" DNA, ale ujawniane są także szczególnie interesujące przypadki upakowania funkcjonalnej informacji genetycznej, zwłaszcza osadzenie wiadomości genetycznych w innych wiadomościach genetycznych - innymi słowy, podwójne kodowanie informacji. Jak pisze Meyer: ,niczym matrioszki, egzony i introny mają w sobie zakodowane wiele wiadomości genetycznych, ale i same są częścią większej wiadomości genetycznej”. ${ }^{72} \mathrm{~W}$ komórce zachodzi coś analogicznego do kodowania tajnych wiadomości w zrozumiałym tekście, opowiadającym o zwyczajnych sprawach, takich jak stan pogody, problemy osobiste czy osiągnięcia zawodowe. Tę drugorzędową informację, zakodowaną w informacji pierwszorzędowej, może odczytać ktoś, kto jest w posiadaniu klucza deszyfrującego, umożliwiającego zlokalizowanie i przethumaczenie ukrytego prze-

\footnotetext{
${ }^{71}$ Por. Wells, The Politically Incorrect Guide..., s. 204-205. Por. też Forrest M. Mims III, „Avian Influenza and UV-B Blocked by Biomass Smoked”, Environmental Health Perspectives December 2005, http://findarticles.com/p/articles/mi_m0CYP/is_12_113/ai_n27862923/ (10.04. 2010).

${ }^{72}$ MeYer, Signature in the Cell..., s. 463.
} 
kazu. W środowisku komórkowym rolę klucza, pozwalającego zidentyfikować, udostępnić i przepisać informacje genetyczne ukryte w innych informacjach genetycznych (to jest informacje transkrybowane na RNA i odczytywane podczas translacji w rybosomie, dzięki czemu tworzą się pewne rodzaje białek, jak też strukturalne i regulatorowe RNA, które nie są zakodowane w egzonach lub w ich pierwszorzędowej informacji) pełnią wspólnie kody RNA wyższego rzę$\mathrm{du}$, odpowiednie białka oraz enzymy tnące i łączące fragmenty DNA. Meyer argumentuje, że utworzenie sensownej wiadomości w innej sensownej wiadomości, i to w taki sposób, by jedna nie wpływała zakłócająco na drugą, jest zadaniem znacznie trudniejszym niż utworzenie jednej takiej informacji, a więc zmniejsza się też prawdopodobieństwo, że jest to rezultat działania ślepych sił ewolucyjnych. Łatwo natomiast można to wyjaśnić w ramach teorii inteligentnego projektu, a to, że inteligencja potrafi prowadzić do takich skutków, znajduje niezależne potwierdzenie $\mathrm{w}$ świecie wytworów ludzkich. ${ }^{73}$

Okazuje się ponadto, że genom ma organizację hierarchiczną, co usprawnia wyszukiwanie i dostęp do odpowiednich informacji genetycznych, jak i manipulowanie nimi oraz wyrażanie ich. Ta hierarchiczna organizacja genomu przypomina komputerowy system porządkowania plików danych w folderach. Jak pisze Meyer, „tak jak słowa układają się w zdania, a zdania w akapity, tak nukleotydy układają się w geny, zaś geny w specyficznie zorganizowane grupy genów". ${ }^{74}$ Różne geny (pliki danych) występują w nielosowych zgrupowaniach genowych (folderach) wzdłuż nici DNA. „Foldery” genowe są z kolei nielosowo pogrupowane wzdłuż chromosomów, tworząc foldery wyższego rzędu, czyli „superfoldery”. Co więcej, „superfoldery” genowe tworzą jeszcze większe zespoły genów, które można nazwać „megafolderami”. Wszystko to ułatwia dokonywanie rozmaitych operacji na informacji genetycznej, a — zdaniem Meyera — powstanie takiej zoptymalizowanej organizacji genomu jest niespodziewane po ślepych procesach naturalnych, przebiegających na zasadzie prób i błędów, które powinny raczej doprowadzić do utworzenia genomu znacznie bardziej chaotycznego. ${ }^{75}$

\footnotetext{
${ }^{73}$ Por. Meyer, Signature in the Cell..., s. 461-467.

${ }^{74}$ Meyer, Signature in the Cell..., s. 467.

${ }^{75}$ Por. Meyer, Signature in the Cell..., s. 467-470.
} 
Jeszcze inną cechą organizmów żywych, którą Meyer uznaje za nieoczekiwaną z punktu widzenia teorii naturalistycznych, jest to, że ekspresja modułów genetycznych niższego poziomu determinowana jest przez organizm, stanowiący kontekst informacyjny zarówno o charakterze genomicznym, jak i pozagenomicznym, niezapisanym w DNA. Wbrew wcześniejszym przewidywaniom okazało się, że kodujące sekwencje DNA nie są jedynym wyznacznikiem funkcji produktów genów w trakcie rozwoju embrionalnego, a więc podobne, homologiczne geny nie tworzą homologicznych struktur w odmiennym kontekście informacyjnym. Plany budowy ciał najwyraźniej określa coś innego niż informacja zawarta w DNA. Taki odgórny — w odróżnieniu od oddolnego — zależny od kontekstu kierunek determinowania funkcji produktów genów jest w pełni zrozumiały $\mathrm{z}$ perspektywy teorii inteligentnego projektu i ma odpowiednik choćby w ludzkich systemach komunikacji — wskazuje Meyer. Odmienny kontekst może poszczególnym słowom, zdaniom, a nawet całym fragmentom tekstu nadawać zupełnie inny sens. Oto przykład dwóch takich zdań: „«to ciasto jest przepyszne» - powiedział entuzjastycznie” oraz „«to ciasto jest przepyszne» - powiedział sarkastycznie”. Podobnie jak w przypadku genów, ten sam zbiór słów, bez zmieniania ich znaczeń, można też tak zreorganizować, by jako całość przedstawiał jakiś inny sens - na przykład ostatnie czterdzieści trzy słowa Mowy Gettysburskiej Abrahama Lincolna można poprzestawiać tak, by wyrażały manifest anarchistyczny. ${ }^{76}$

Chociaż odkrycia te nie były dokonywane przez teoretyków projektu, poszukiwanie takich cech organizmów można $\mathrm{z}$ pewnością uznać za jedne z najbardziej interesujących badań, do jakich stanowczo zachęca teoria inteligentnego projektu. Szczególne, hierarchiczne uporządkowanie informacji oraz wyszukane, skomplikowane systemy przechowywania, kodowania i przetwarzania informacji to coś, czego w bardziej naturalny sposób można spodziewać się po inteligentnym projektancie niż po „ślepym zegarmistrzu”. Co więcej, odkrycie takich cech prowadzi do dalszych problemów badawczych. Nie wiadomo na przy-

\footnotetext{
${ }^{76}$ Por. Meyer, Signature in the Cell..., s. 471-477. Przekształcenie Mowy Gettysburskiej w manifest anarchistyczny można znaleźć w: Paul Nelson and Jonathan Wells, „Homology in Biology: Problem for Naturalistic Science and Prospect for Intelligent Design”, w: John Angus Campbell and Stephen C. Meyer (eds.), Darwinism, Design, and Public Education, Michigan State University Press, East Lansing, Michigan 2003, s. 317 [303-322].
} 
kład, gdzie rezyduje cała informacja pozagenomiczna (czy ontogenetyczna), można więc podejmować próby jej zlokalizowania, a ponadto zbadać bliżej jej wpływ na informację niższego poziomu czy też opracować metody jej pomiaru, wziąwszy pod uwagę to, że w przeciwieństwie do cyfrowej i statycznej informacji genomicznej ma ona charakter strukturalny i dynamiczny, oraz ustalić ewentualne granice jej zmienności. ${ }^{77}$ Oczywiście, mimo iż istnienie tych cech wydaje się bardziej naturalne z perspektywy teorii inteligentnego projektu, można podejmować próby naturalistycznego ich wyjaśnienia, natomiast teoretycy projektu mogą z krytycznym podejściem oceniać wiarygodność tych scenariuszy.

Dość egzotyczną, choć związaną częściowo z omówionymi w kilku powyższych akapitach kwestiami, możliwość badań w ramach teorii inteligentnego projektu wskazuje William Dembski. Jeżeli organizmy żywe są wytworem inteligentnego projektanta, to być może oprócz informacji potrzebnych do ich funkcjonowania zawierają też informacje, które nie mają znaczenia funkcjonalnego z perspektywy samych organizmów, ale mogą dostarczyć cennej wiedzy na temat ich funkcjonowania osobom je badającym. Te informacje tworzyłyby coś w rodzaju podręcznika użytkownika czy instrukcji obsługi, jakie producenci dołączają do różnych urządzeń lub maszyn. Całość instrukcji nie musi być zapisana w każdym organizmie, ale mogła zostać na przykład rozdzielona na wiele różnych, spokrewnionych ze sobą organizmów. Jeśli taki biologiczny „podręcznik użytkownika" istnieje, to stanowi z pewnością dobrze ukrytą informację, podobnie jak ma to miejsce w systemach steganograficznych (steganografia to nauka o niewykrywalnym sposobie przekazywania komunikatów, różniąca się od kryptografii tym, że w niej niejawna ma być nie tylko treść komunikatu, ale i samo jego istnienie - a to można zrobić oczywiście z mniejszym lub większym powodzeniem). Poszukując takiej informacji, teoretycy projektu prowadziliby analizę steganograficzną, opracowując odpowiednie testy statystyczne w celu jej wykrycia, a gdyby ją wykryto, można by zidentyfikować algorytmy, które zastosowano, aby ją ukryć. Jest właściwie oczywiste, że ewentualne odkrycie biologicznej ,instrukcji obsługi” (co może jednak pozostać wyłącznie w sferze fantastyki naukowej) byłoby potężnym, a nawet zabójczym ciosem dla teorii natu-

\footnotetext{
${ }^{77}$ Por. Meyer, Signature in the Cell..., s. 478.
} 
ralistycznych, które w żaden sposób nie przewidują możliwości powstania informacji służącej nie przenoszącym ją organizmom, lecz ich badaczom. ${ }^{78}$

$\mathrm{Na}$ temat zarzutu, że teoria inteligentnego projektu byłaby „hamulcem” nauki, można stwierdzić też coś więcej. Otóż zgodnie z tą teorią nie wszystko w przyrodzie jest zaprojektowane lub przynajmniej nie wszystko można uznać za takie na podstawie świadectw empirycznych. A więc jeżeli nawet stwierdzenie istnienia projektu ucina dalsze naukowe badania na temat wykonawcy lub sposobu wytworzenia projektu i gdyby nawet teoria inteligentnego projektu nie inspirowała żadnych nowych badań, to nadal można prowadzić zwykłe, naturalistyczne badania genezy struktur nieprzejawiających oznak zaprojektowania. Ponadto rozstrzygnięcie problemów związanych z kwestią pochodzenia na korzyść teorii inteligentnego projektu $\mathrm{w}$ żadnym razie nie eliminuje potrzeby prowadzenia badań nad normalnym funkcjonowaniem i budową świata przyrody. ${ }^{79} \mathrm{~W}$ takim wypadku można by mówić co najwyżej, że teoria ta jest „hamulcem” nauki tylko w określonym zakresie, co samo w sobie nie musi być czymś złym, jeśli uznać, że nauka może natrafić na coś, czego - mimo iż teoretycznie mogłaby — nie będzie w stanie wyjaśnić ze względu na praktyczną trudność lub nawet niemożliwość uzyskania odpowiednich informacji (por. też przyp. 45).

Wbrew twierdzeniom krytyków teoria inteligentnego projektu niewątpliwie umożliwia i zachęca do prowadzenia różnego rodzaju badań naukowych a wyżej omówione nie wyczerpują listy możliwości. Można zauważyć, że niektóre badania są już poniekąd realizowane przez samych teoretyków projektu, aczkolwiek aby mogło to wywrzeć większe wrażenie na społeczności naukowców, pożądane byłoby podjęcie zdecydowanie intensywniejszych działań w tym względzie. Inne kierunki badań z nie do końca jasnych powodów pozostają na-

\footnotetext{
${ }^{78}$ Por. Dembski, „Tematy badań...”, s. 144-146; Dembski, The Design Revolution..., s. 316317; Dembsкi, „Becoming a Disciplined Science...”; IDEA Center, „FAQ: Wouldn’t Intelligent Design...”; IDEA Center, „FAQ: What Sort of Progress...”.

${ }^{79}$ Por. Peter Cook, Evolution versus Intelligent Design: Why All the Fuss? The Arguments for Both Sides, New Holland Publishers, Australia 2006, s. 52-53; Timothy G. Standish, „Cutting Both Ways: The Challenge Posed by Intelligent Design to Traditional Christian Education”, w: Dembski (ed.), Darwin's Nemesis..., s. 119-120 [117-132]; William S. Harris and John H. CALVERT, „Intelligent Design: The Scientific Alternative to Evolution”, The National Catholic Bioethics Quarterly Autumn 2003, s. 556 [531-561], http://www.intelligentdesignnetwork.org/NC BQ3_3HarrisCalvert.pdf (18.07.2009).
} 
tomiast zupełnie niewypróbowane. Być może przyczyna tego stanu rzeczy tkwi w pewnym przynajmniej stopniu w trudności prowadzenia takich badań w praktyce. Jednak bez względu na dokładną tego przyczynę, nie ulega raczej wątpliwości, że ewentualne odniesienie sukcesu teorii inteligentnego projektu w świecie nauki wymaga od jej zwolenników większego zaangażowania w wysiłek tworzenia i aktywnej realizacji programu badawczego niż można to było dotychczas zaobserwować z ich strony.

Dariusz Sagan

\section{On the Research Program of Intelligent Design Theory}

\section{Summary}

According to intelligent design theory, certain biological and cosmic phenomena were designed by an intelligent being that could just as well be natural as supernatural, and this design is scientifically detectable. However, critics pose an objection that unscientific character of this theory is discernible in that it is not useful for science because it does not inspire new scientific research and thus it is stopping the progress of science. The lack of research program or scarcity of carried out research projects is recognized also by the proponents of that theory, but the article presents some possible research which intelligent design theory may inspire. Although the development of research program by design theorists is not necessary from the methodological perspective, in practice the potential scientific success of intelligent design theory depends largely on whether the proponents of this approach would convince scientists that thanks to it they can do something, that it could be a good, fruitful research guide, and thus demands more commitment of design theorists to the effort of forming and actively accomplishing a research program than it could have been observed so far.

Keywords: irreducible complexity, specified complexity, information, Biologic Institute, signs of design, limits of evolution, ,junk” DNA, genetic algorithm, steganography.

Słowa kluczowe: nieredukowalna złożoność, wyspecyfikowana złożoność, informacja, Biologic Institute, oznaki projektu, ograniczenia ewolucji, „śmieciowy” DNA, algorytm genetyczny, steganografia. 